\title{
Volcanology and inflation structures of an extensive basaltic lava flow in the Payenia Volcanic Province, extra-Andean back arc of Argentina
}

\author{
"Mauro Ignacio Bernardi', Gustavo Walter Bertotto ${ }^{1}$, Alexis Daniel Ponce', \\ Yuji Orihashi² ${ }^{2}$ Hirochika Sumino ${ }^{3}$
}

\author{
I Instituto de Ciencias de la Tierra y Ambientales de La Pampa (CONICET-Universidad Nacional de La Pampa), Santa Rosa, La Pampa. \\ mi_bernardi@hotmail.com; gwbertotto@yahoo.com.ar; poncealexis_wini@hotmail.com \\ 2 Earthquake Research Institute, University of Tokyo, Tokyo, Japan. \\ oripachi@eri.u-tokyo.ac.jp \\ 3 Department of Basic Science, Graduate School of Arts and Sciences, University of Tokyo, Tokyo, Japan. \\ sumino@igcl.c.u-tokyo.ac.jp \\ *Corresponding Author: mi_bernardi@hotmail.com
}

\begin{abstract}
The El Puesto lava flow is located in the Payenia Volcanic Province (central-western Argentina), has a length of $70 \mathrm{~km}$ and is Middle Pleistocene in age $(0.200 \pm 0.027 \mathrm{Ma})$. The flow shows a P-type pahoehoe structure and exhibits several inflation structures, mainly tumuli and also inflation ridges and lava rises. Lava rise pits and radial or annular clefts are common features associated with inflation structures. The gentle slope on which the flow moved $\left(\approx 0.5^{\circ}\right)$ allowed the lateral coalescence of lobes at the flow front and the development of an external rigid crust that insulated the liquid core. Lava tunnels are frequent and the lava tunnel named "Cueva de Halada" which is located at its medium portion is the best example of a drainage master tube which formed from the cooling of the crust around a stable inflated flow. Tumuli alignments and long inflation ridges reveal the existence of larger tunnels within the flow. Inflation structures may occur in high concentration belts that converge on a single main belt which is assigned to an anastomosed network of internal flow pathways within the main lava body. The development of inflation structures and lava tunnels require low to moderate effusion rates. An average lava supply rate of $1.8 \times 10^{-4} \mathrm{~m}^{3} / \mathrm{s}$ and an inflation time of about 15 days were estimated for an average tumulus of this flow. A high and sustained supply of low viscosity lava $(\eta '=1550-483 \mathrm{~Pa}$ s) was inferred that initially generated a sheet flow of great areal extension. The reduction in effusion rates could then allowed the development of tunnels that carried lava to the distal fronts, generating localized inflation phenomena throughout the lava flow.
\end{abstract}

Keywords: Lava flow, Inflation structures, Back-arc volcanism, Basalts.

RESUMEN. Volcanología y estructuras de inflación de un extenso flujo de lava basáltica en la Provincia Volcánica Payenia, retroarco extraandino de Argentina. El flujo de lava El Puesto se localiza en la Provincia Volcánica de Payenia (centro-oeste de Argentina), tiene una longitud de $70 \mathrm{~km}$ y se emplazó en el Pleistoceno medio (0,200 $\pm 0,027 \mathrm{Ma})$. La colada muestra una estructura de flujos pahoehoe tipo "P" y exhibe numerosas estructuras de inflación como túmulos, dorsales de inflación y elevaciones de techo plano. Los pozos y las fracturas radiales o anulares de inflación son rasgos comunes asociados a estas estructuras. La colada El Puesto se movilizó sobre una pendiente suave $\left(\approx 0,5^{\circ}\right)$ que favoreció la coalescencia lateral de lóbulos en el frente de la colada y el desarrollo de una corteza externa rígida que aisló térmicamente el núcleo de lava líquida. Los túneles de lava son frecuentes y el túnel de lava conocido como "Cueva de Halada", situado en la porción media del flujo, es un excelente ejemplo de un túnel maestro drenado que se formó a partir del enfriamiento de la corteza externa alrededor de un flujo inflado estable. Los alineamientos de túmulos y las extensas dorsales de inflación revelan la existencia de túneles mayores sin drenar en el interior del flujo. Las estructuras de inflación pueden concentrarse en fajas alargadas que convergen hacia una única faja principal, lo que se interpreta como producto de una red anastomosada de vías internas de transporte del flujo dentro del cuerpo de lava principal. El desarrollo de estructuras de inflación y túneles de lava requieren de tasas de efusión moderadas a bajas. Se estimó una tasa promedio de suministro de lava de $1,8 \times 10^{-4} \mathrm{~m}^{3} / \mathrm{s}$ y un tiempo de inflación de aproximadamente 15 días para 
un túmulo típico de esta colada. Se infirió un suministro alto y sostenido de lava de baja viscosidad ( $\eta$ ' $=1550-483$ Pa s) que inicialmente generó un flujo tabular de gran extensión areal. La reducción en las tasas de efusión permitió luego, el desarrollo de túneles a través de los cuales la lava se transportaba hacia los frentes distales, generando fenómenos de inflación localizada en todo el ámbito de la colada.

Palabras clave: Flujo de lava, Estructuras de inflación, Volcanismo de retroarco, Basaltos.

\section{Introduction}

One of the most common forms of volcanic activity on Earth is that in which lava flow effusions take place; however, extremely long subaerial lava flows are a rare feature on our planet. The main cases cited in the literature correspond to the Quaternary lava flows that are situated in northeastern Australia, known as Undara (e.g., Atkinson and Atkinson, 1995) and Toomba (e.g., Stephenson and Griffin, 1976; Stephenson et al., 1998) with lengths greater than 100 $\mathrm{km}$; the lavas from the Neogene basaltic plateau of the Columbia River, USA (e.g., Waters, 1961; Self et al., 1996); and the Thjorsa lava flow (>140 km) of 8.5 ka age (Hjartarson, 1988; Halldorsson et al., 2008) in Iceland. The long pahoehoe lava flows of the basaltic plateau of the Deccan Trap in India, with flows of over $400 \mathrm{~km}$ and reaching up 1,000 km in length in some cases, have been considered the remnants of the longest lava flows on Earth (e.g., Agashe and Gupte, 1971; Keszthelyi et al., 1999; Self et al., 2008). In Argentina, the Payenia Volcanic Province comprises an extensive basaltic plateau localized in the Andean foothills. It is mainly constituted by lava flows associated to Neogene-Quaternary extra-Andean back-arc volcanic activity. At the central region of this volcanic province, Pasquaré et al. (2008) and Espanon et al. (2014) describe a single lava flow that reached up to over $160 \mathrm{~km}$ from its source which is localized in the Payún Matrú volcanic field. It was named Pampas Onduladas and it has been proposed as the most extensive Quaternary lava flow on Earth. In spite of this, Pampas Onduladas lava flow is associated to other contemporaneous and very extensive lava flows named Pampa de Los Carrizales (Pasquarè et al., 2008) which reached up $181 \mathrm{~km}$ in length (Bernardi, 2016) and was extruded from La Carbonilla fracture (Llambías, 1966) which is the same fissural effusion center as lavas of Pampas Onduladas. The lavas of Pampa de Ranquelcó and Pampa de Luanco, of 116 and $122 \mathrm{~km}$ in length, respectively (Bernardi, 2016) and the El Corcovo lava flow, of $70 \mathrm{~km}$ in length (Bernardi et al., 2015;
Bernardi, 2016) situated in southern Payenia comprise other lava flows of notable length (Fig 1).

Based on observations on the behavior of Hawaiian active lava flows, Hon et al. (1994) proposed a model for effusions of moderate volume, also applicable to high-volume lava eruptions, known as inflation. Initially, lava advances through a series of individual lobes that coalesce laterally and increase in thickness thanks to the injection of lava below an outer cooling crust having ductile behavior, which becomes brittle as it cools and thickens. This crust supports the increasing pressure of the addition of lava to the isolated liquid core. Initial inflation is general throughout the entire lava body and it becomes localized as the lava movement is restricted to an internal network of lava tubes.

According to this model, pahoehoe flows develop through a combination of areal dispersal and inflation with the formation of ruptures and lava squeeze-ups through the margins of the lobes (Hon et al., 1994; Keszthelyi and Denlinger, 1996; Harris et al., 2007). Inflation is the dominant process until the internal lobule pressurization reaches values that are large enough to break the flow margins and start again a cycle of lateral dispersion-inflation (Hoblitt et al., 2012). At moderate rates of effusion, inflation and cortical growth occur at similar rates.

The inflation process occurs locally and the flow advances from leaks through fractures caused by swelling. In contrast, when the effusion rates are higher and sustained over time, the flow is able to inflate evenly, resulting in a sheet flow which evolves into a hummocky flow when effusion rates begin to decrease. The hummocky flow generates a micro-relief defined by inflation structures, which modifies the previous smooth surface of the flow (Self et al., 1998). These structures include: tumuli, flat-roof lava rises, lava-rise ridges and lava-rise pits (Walker, 1991; Hon et al., 1994; Whitehead and Stephenson, 1998). It is also common that flow crosssections exhibit massive and vesicular sectors, where patterns of vesicle size distribution and changes in vesicle density are regularly observed (e.g., Aubele 


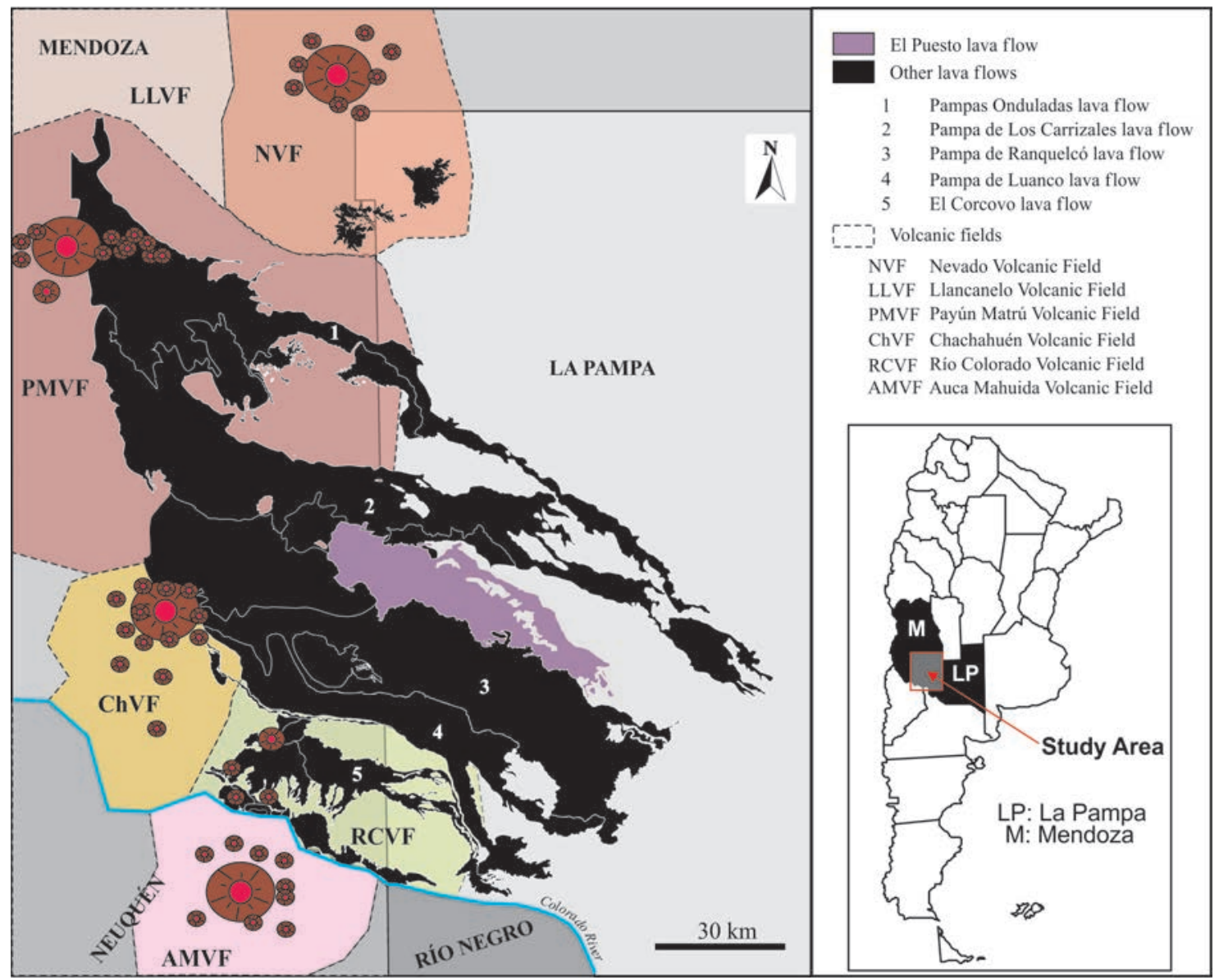

FIG. 1. Map of the southeastern region of Payenia Volcanic Province indicating some of the main volcanic fields in which it was divided, according to Bermúdez et al. (1993), Ramos and Folguera (2011) and Gudnason et al. (2012). The main lava flows considered in this work are also shown.

et al., 1988; McMillan et al., 1989; Manga, 1996; Cashman and Kauahikaua, 1997).

These morphological and structural features that are related to the inflation mechanism have been observed in numerous ancient lava flows (e.g., Hjartarson, 1988; Thordarson and Self, 1996; Keszthelyi et al., 1999; Whitehead and Stephenson, 1998; Pasquaré et al., 2008), particularly in those of considerable extension, from which it was postulated that this process was essential in the development and emplacement of these lava flows.

The main objective of this work is to characterize the emplacement mode of the El Puesto lava flow (EPLF) and to recognize and parameterize the inflation process from the different inflation structures that it generates.

\section{Geological setting}

\subsection{Payenia Volcanic Province}

Payenia Volcanic Province comprises an extensive basaltic plateau localized in the extra-Andean backarc sector of central-western Argentina, 460 to $540 \mathrm{~km}$ east of the Chile Trench. It extends between $33^{\circ} 40^{\prime} \mathrm{S}$ and $38^{\circ} \mathrm{S}$ and from the current volcanic arc to the Salado River Valley covering central-southern Mendoza, northern Neuquén and western La Pampa provinces (Fig. 1).

Payenia comprises the greatest NeogeneQuaternary volcanic province of South America with more than 800 monogenetic cones (e.g., Inbar and Risso, 2001; Bertotto et al., 2006; Risso et al., 
2008; Mazzarini et al., 2008; Folguera et al., 2009). Geochemically, rocks range from basalts to andesites, with arc to intraplate signatures (e.g., Kay et al., 2006; Ramos and Kay, 2006; Bertotto et al., 2009). Payenia has been divided into several volcanic fields according to their geographical and geochemical characteristics (Bermúdez et al., 1993; Ramos and Folguera, 2011; Gudnason et al., 2012). The main volcanic fields are: Diamante (not shown in Fig. 1), Nevado, Llancanelo, Payún Matrú, Chachahuén, Auca Mahuida and Tromen (not shown in Fig. 1). Field relationships (e.g., Groeber, 1946; González Díaz, 1979) and radiometric dates (e.g., Kay et al., 2006; Quidelleur et al., 2009; Folguera et al., 2009; Germa et al., 2010; Gudnason et al., 2012; Ramos et al., 2014; Dyhr et al., 2013; Marchetti et al., 2014; Espanon et al., 2014; May et al., 2018) allowed to infer a continuous igneous activity in Payenia from Miocene to Holocene, with a gap between late Miocene and early Pliocene. Basaltic units that form Payenia have been considered as indicators of extensional events that were produced after a Tertiary compressive stage. Bermúdez et al. (1993) indicated that the melts were generated from thermal and mechanical disturbances of the mantle. Meanwhile, Kay (2002) and Kay et al. (2004, 2006) related the generation of these magmas with the melting of a hydrated mantle after a low-angle subduction episode which occurred between 8 and 5 Ma (Late Miocene).

\section{EI Puesto lava flow}

\subsection{Location and eruptive center}

The El Puesto lava flow (EPLF) comprises a basaltic flow of notable extension located in the southern-central sector of the Payenia Volcanic Province (Fig. 1). The effusion center was the Morado volcano, located at $36^{\circ} 51^{\prime} \mathrm{S}$ and $68^{\circ} 21^{\prime} \mathrm{W}$ (Fig. 2A) and the EPLF culminated its advance in the proximities of the La Copelina salt flat $\left(37^{\circ} 12^{\prime} \mathrm{S}-67^{\circ} 35^{\prime} \mathrm{W}\right)$.
Bertotto (2003) describes the Morado volcano as an elevation with semicircular contour without crater. It shows an average height of $25 \mathrm{~m}$ with respect to the surrounding surface, an average basal diameter of $260 \mathrm{~m}$ and an upper diameter of approximately $45 \mathrm{~m}$. It exhibits slopes with angles between $11^{\circ}$ and $17^{\circ}$ and it is constituted by lava flows, pyroclasts and subvertical vesicular dykes.

The rocks of the Morado volcano were assigned to the Pliocene (Wichmann, 1928), Pleistocene (Sobral, 1942) and Holocene (Núñez, 1976) by geological relationships. Here we present a K-Ar whole rock age of $0.200 \pm 0.027 \mathrm{Ma}$ (Middle Pleistocene) for a sample of the EPLF (Table 1). The analyzed sample (M129, lat/long: $36^{\circ} 51^{\prime} \mathrm{S} / 68^{\circ} 21^{\prime} \mathrm{W}$, Fig 2a) was collected from the massive core of the lava flow, in the southeast sector of the Morado volcano (site EP1 in Fig. 2A). Detailed petrography of the sample is described at the Petrology Features section. The age was obtained by the "unspiked K-Ar" method. The Ar analysis was performed using a noble gas mass spectrometer (modified VG5400/MS-III) at the University of Tokyo, Japan. The errors in the determination of ${ }^{40} \mathrm{Ar}$ and ${ }^{40} \mathrm{Ar}{ }^{36} \mathrm{Ar}$ ratio were estimated at $5 \%$ and $0.2 \%$, respectively, based on repeated measurements of the atmospheric standard containing $1.5 \times 10^{-7} \mathrm{~cm}^{3} \mathrm{STP}$ of ${ }^{40} \mathrm{Ar}$. The concentration of $\mathrm{K}$ was determined by X-Ray fluorescence Spectrometry, XRF (Phillips PW2400) for an aliquot of the same total rock sample that was used for the analysis of Ar. The analytical precision was checked using the international rock standard JB-1a (Geological Survey of Japan). Details of the procedure applied with respect to the K-Ar dating are described by Nagao et al. (1991) and Orihashi et al. (2004).

\subsection{Geomorphometry}

The El Puesto lava flow presents a predominantly southeasterly sense of movement with some minor spills to the west, northwest, and south of the eruptive center. The flow reached a longitudinal development

TABLE 1. ANALYTICAL DATA OF ANALYZED SAMPLE.

\begin{tabular}{|cccccc|}
\hline Sample & $\mathbf{K}$ & ${ }^{40} \mathbf{A r R a d}$ & AIR fraction & Age \\
$(\mathbf{w t} \%)$ & $\left.\mathbf{( 1 0 - 8} \mathbf{~ c m}^{\mathbf{3}} \mathbf{S T P} / \mathbf{g}\right)$ & ${ }^{38} \mathbf{A r}{ }^{36} \mathbf{A r}$ & $(\%)$ & Ma $)$ \\
\hline M129 & $0.829 \pm 0.041$ & $0.644 \pm 0.084$ & $0.18805 \pm 0.00079$ & 96.51 & $0.200 \pm 0.027$ \\
\hline
\end{tabular}


of $70 \mathrm{~km}$, has an average width of $11 \mathrm{~km}$ with a maximum of $20 \mathrm{~km}$ in its middle sector and covers an area of approximately $856 \mathrm{~km}^{2}$ (Fig. 2A). The flow presents a wide coverage of sandy sediments on the roof, which only highlight the inflated structures. These local inflation landforms reach variable heights of between 3 and $8 \mathrm{~m}$ with respect to the adjacent terrain. For those sectors of the flow that show large-scale inflation (areas greater than $3 \mathrm{~km}^{2}$ ) an average thickness of up to $5 \mathrm{~m}$ was determined. An estimation of the volume of lava for this flow yielded a minimum value of $4 \mathrm{~km}^{3}$.

Initially, the EPLF advanced as a single front over a lavic substrate conformed in the northern sector by the southern margin of the Pampa de Los Carrizales lava flow (Pasquarè et al., 2008; Bernardi, 2016) and in the central and southern sectors by the Llano del Tapa and Pampa de Ranquelcó lava flows (Bernardi, 2016, Fig. 2A). At $12 \mathrm{~km}$ to the east of the extrusion site the northern margin of the EPLF shows the first of numerous and successive northeast-trending spills into a wide erosion channel, known as Bardas Bayas depression (Fig. 2A). The northeast margin of this depression partially dissects the lavas of the Pampa de Los Carrizales flow and also exposes Cretaceous-Paleogene calcareous rocks belonging to the Neuquén basin, which are underlying these lavas. The Bardas Bayas depression has a variable width of between 5 and $8 \mathrm{~km}$ and extends for about $60 \mathrm{~km}$ with a southeast direction, culminating in the La Copelina salt flat. The lava flows that came into the erosive channel gave rise to the formation of a secondary flow, parallel to the main body, which occupied almost all of the depression (northern branch, Fig. 2A). This branch has a length of $46 \mathrm{~km}$ and widths varying between 1.5 and $5 \mathrm{~km}$.

The EPLF has an elongated morphology with irregular margins and numerous kipukas, which lead to infer a substrate with topographic irregularities. This last aspect could be the result of the presence of inflation structures in the substrate, as observed in the exposed sectors of the lava flows that underlies and borders the EPLF.

The highest elevation in the area of the Morado volcano (site EP1) has an altitude of $960 \mathrm{~m}$ a.s.1., while the lowest elevation of the emplacement area of the EPLF corresponds to La Copelina salt flat with an altitude of $550 \mathrm{~m}$ a.s.1. (section A-A', Fig. 2B).

\subsection{Morphology and structure}

The cross-sections of outcrops of the EPLF show the typical features of a P-type pahoehoe flow (Wilmoth and Walker, 1993) with two external vesicular sectors surrounding a massive core, in which vesicular segregation structures with cylindrical and tabular geometries were observed (Bernardi et al., 2016, 2018). Notwithstanding, the most important structural aspects observed in the EPLF are those which were originated mainly by local accumulations of lava. A modal counting of inflation structures was carried out on the base of satellite images (Google Earth) in which three areas of between 40 and $60 \mathrm{~km}^{2}$ located in the proximal, medium and distal portions of the flow were delimited. Out of a total of 3,000 quantified points, it was determined that between 81 and $85 \%$ of the inflation structures corresponds to tumuli (Figs. 3A and 3B) and lava-rise ridges (elongated tumuli) and between 15 and $19 \%$ corresponds to flat roof lava rises (Figs. 3C and 3D). These latter type of structures usually present internal holes called lavarise pits (Figs. 3E and 3F) corresponding to sectors of the structure that remained without inflation. Other types of observed structures are those related to the displacement and the internal interactions of the flow and between the flow and the relief of the substrate. Those landforms comprise pressure ridges and kipukas.

Tumuli appear isolated and frequently grouped and associated with flat roof lava rises and lava-rise ridges in highly-concentrated inflation structures zones. The most common morphologies of the tumuli are lenticular and ovoid, and their longitudinal axes are normally straight but often show a slight curvature. Axial and radial fractures are a common feature of the tumuli; they are known as inflation cleft and exhibit "Y" patterns (Figs. 4 and 5A). These domed structures have average lengths of between 30 and $50 \mathrm{~m}$, with some individuals with lengths up to $80 \mathrm{~m}$, widths between 10 and $20 \mathrm{~m}$ and heights between 2 and $5 \mathrm{~m}$. External edges exhibit dips ranging from $35^{\circ}$ to $45^{\circ}$. Tumuli exhibit an external crust with extensive polygonal joints (Fig. 5B). The inflation clefts are then formed following the planes of weakness resulting from this fracturing by cooling of the rigid outer crust.

The internal walls of the axial inflation clefts show slightly more closed dip angles, varying between $45^{\circ}$ and $70^{\circ}$ (Fig. 5C). The widths of the 

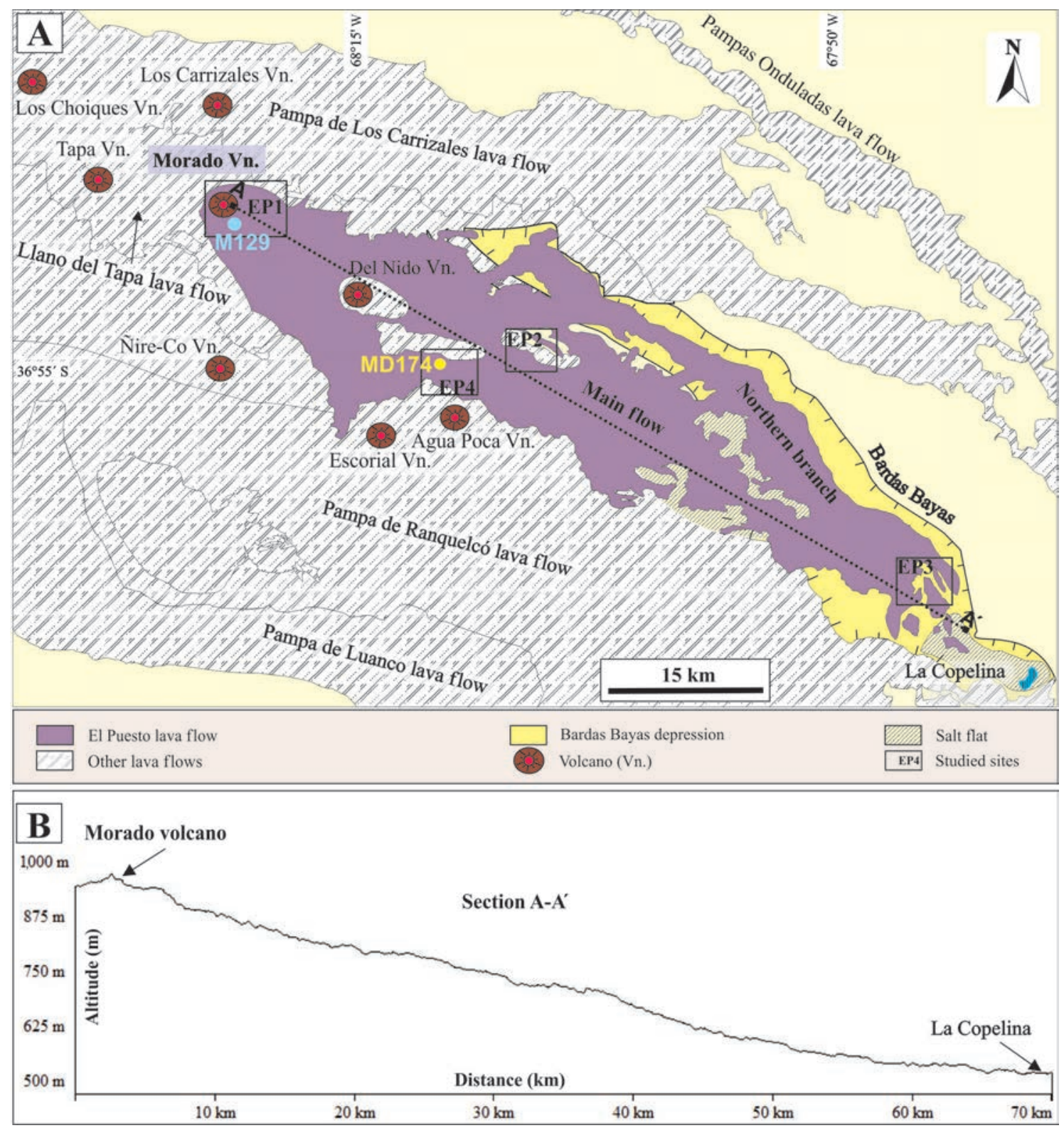

FIG. 2. El Puesto lava flow. A. Detailed map of the EPLF indicating the field relationship with other lava flows, the eruptive center (Morado volcano) location and the trace of the A-A' longitudinal section. Also indicated are the nearby volcanoes and the sites studied in the field (EP1, EP2, EP3 and EP4). The dots indicated as MD174 and M129 correspond to the samples of the chemical and K-Ar analysis, respectively; B. A-A' longitudinal section of the EPLF.

fractures measured on the roof of the tumuli vary between 2 and $3 \mathrm{~m}$ and are partially filled with sandy sediments and dense vegetation. The depths that were determined in some inflation clefts with scarce sedimentary filling reach half the thickness of the structure. Frequently, these fractures exhibit injections of massive lava occupying almost all the fracture (Fig. 5D) or localized squeeze-ups coming from the liquid core of the tumuli (Fig. 5E). These feature lead to infer that the propagation of the fracture occurred concomitantly with the formation of the rigid outer crust and the inflation of the 

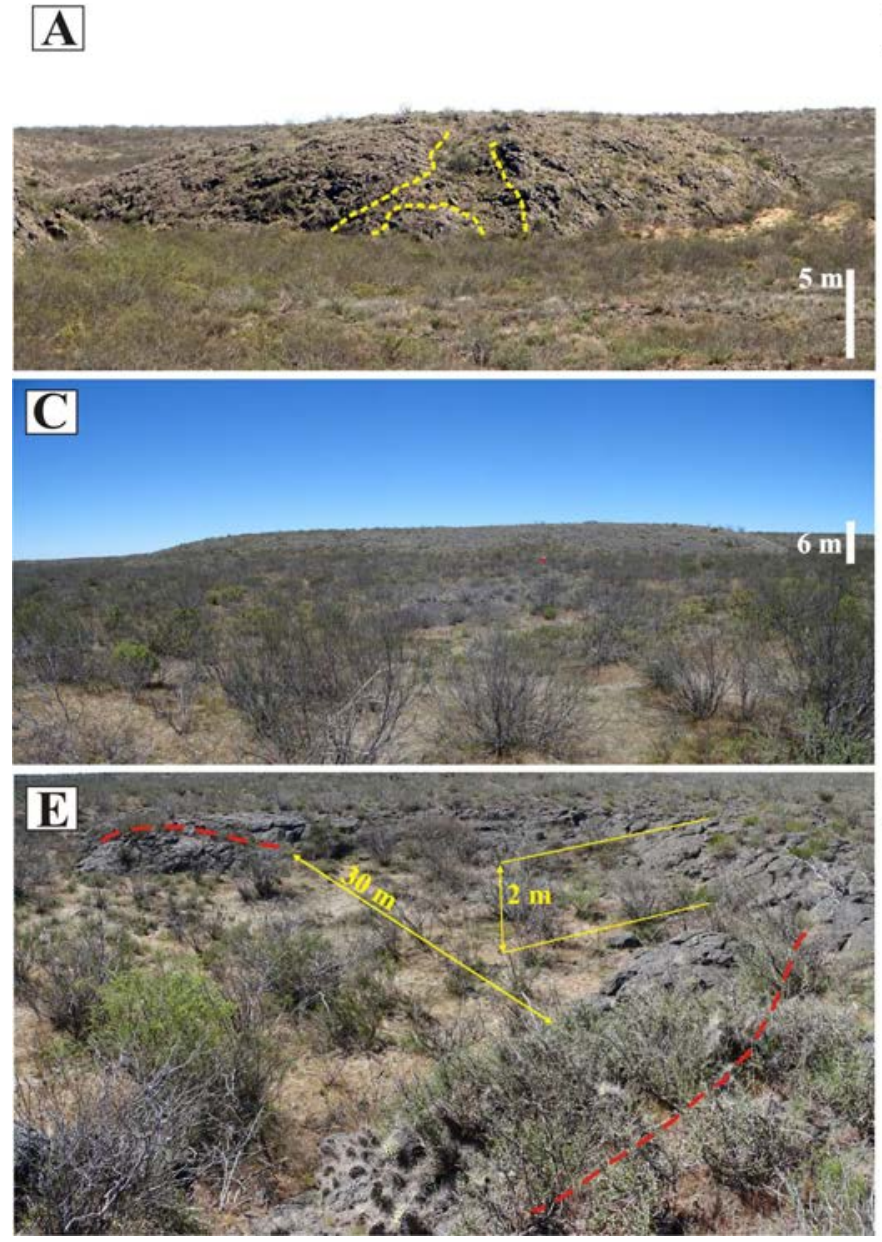

B

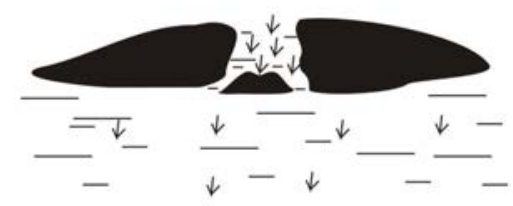

D
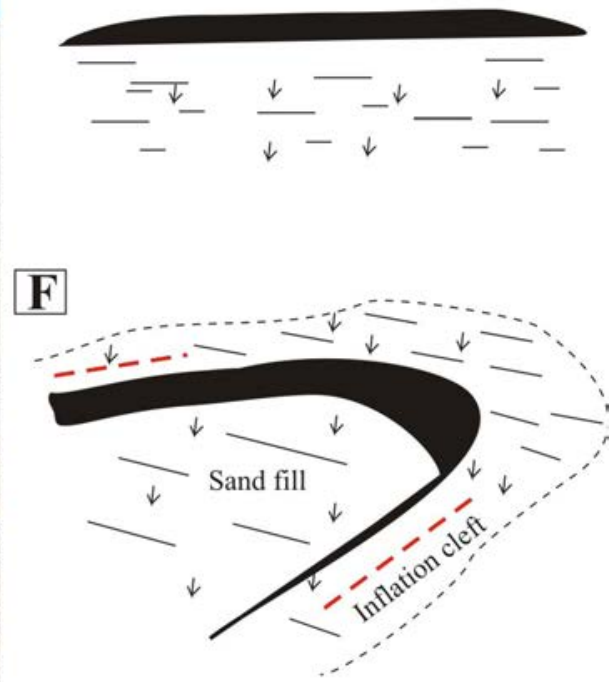

FIG. 3. Inflation structures observed in E1 Puesto lava flow at site EP3. A. Giant tumulus with radial Y-shaped inflation cleft (in red); B. Sketch of figure A; C. Flat roof lava rise; D. Sketch of figure C; E. Lava-rise pit located on the edge of a flat roof lava rise; F. Sketch of figure E. The red dashed lines indicate some segments of the inflation clefts that surround the depressed structure. These fractures were filled with sandy sediments.

tumuli. This latter aspect is also observed in the first centimeters of the cleft walls, as secondary radial vertical to subvertical fractures, with planes that present perpendicular disposal with respect to the inflation cleft trace (Fig 5F). In several of the described tumuli it was observed that the internal structure of the walls of the inflation fractures presents high density vesiculation with diameters of up to $1 \mathrm{~cm}$ in the upper sectors, whereas towards the core of the structure the vesiculation is reduced to less than $25 \%$ and the sizes of the vesicles become greater.

Flat roof lava rises are the second type of dominant inflation structure in the EPLF, and they exhibit dimensions of up to 6 times the average of those of the tumuli. Generally, they present sizes of between 150 and $350 \mathrm{~m}$ length although some isolated cases of kilometric scale were observed, such as the great elliptical elevation of figure $6 \mathrm{~A}$ which exhibits a diameter of $1.5 \mathrm{~km}$ in its major axis. The morphologies of the lava rises are irregular, with rounded and engulfed margins, and sub-circular geometries rarely appear. The heights with respect to the adjacent terrain vary between 2 and $8 \mathrm{~m}$. Flat roof lava rises formed in the same way as tumuli with the exception that the inflation process covered a larger area, and the swelling was uniform in the entire internal perimeter of the structure. Because of this, they do not exhibit the typical axial inflation 

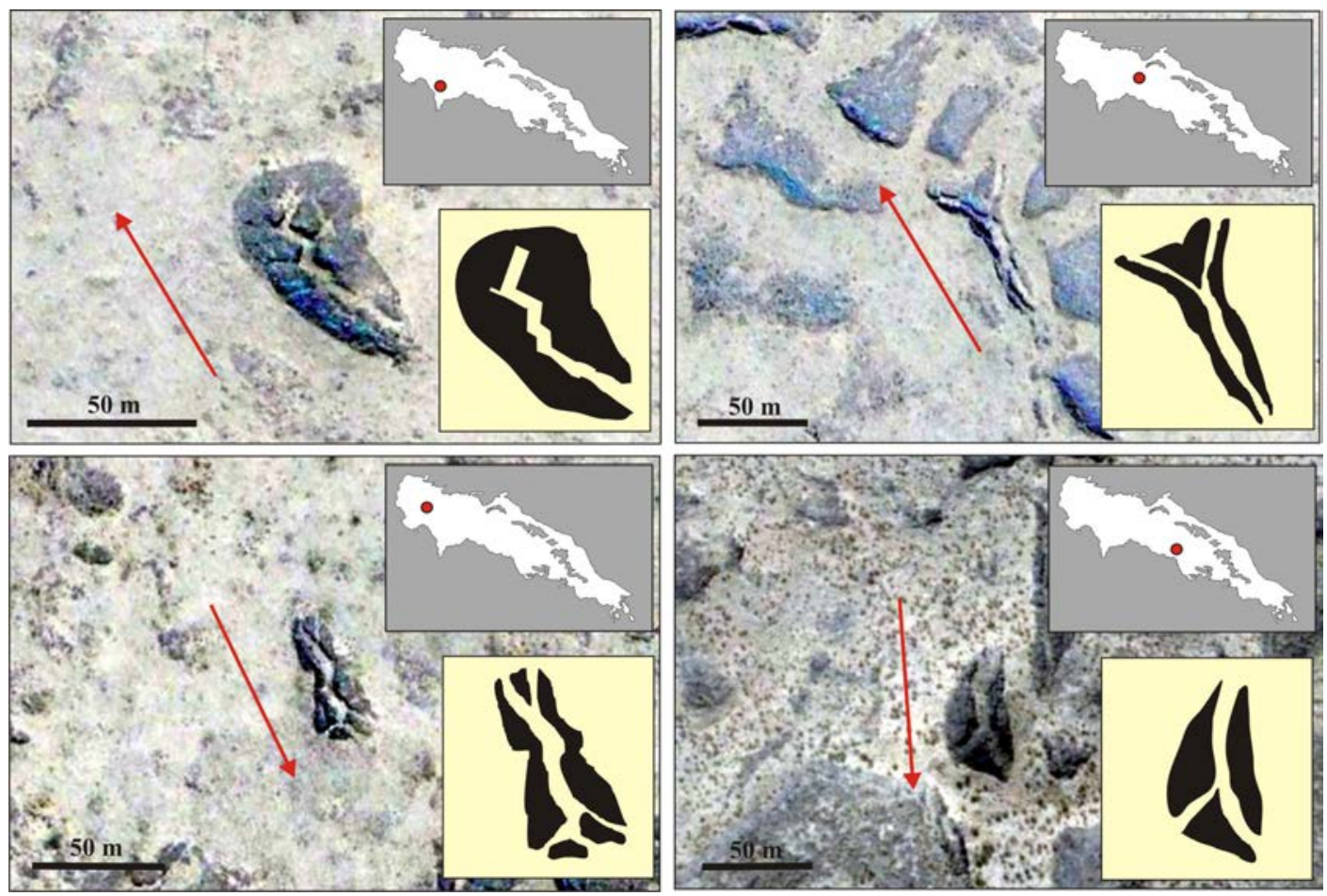

FIG. 4. Satellite images of some typical tumuli observed in El Puesto lava flow displaying different geometries and axial inflation cleft patterns. Red arrows indicate the sense of flow advance, upper inset in each image shows image location in the outline of the El Puesto lava flow (red dot), lower inset shows the sketch of the structure (Google Earth images).

cleft of tumuli, but instead exhibit a sub-vertical annular fracturing that affects the entire perimeter of the structure. Sometimes, flat roof elevations present deflation processes throughout the central sector, maintaining elevated margins and giving rise to a bucket bordered by the perimeter fracture and filled with sandy sediments (Figs. 6B and 6C). This process occurs when the lava exerting pressure under the cooled crust of the elevation is drained away. It is common for flat roof lava rises to be linked by lava-rise ridges, known in these cases as apophyses (Fig. 6D). Lava-rise pits are non-inflated structures that are present as holes in the surfaces of the flat roof lava rises, with sub-circular geometries, diameters varying between 30 and $100 \mathrm{~m}$ and depths of up to $2 \mathrm{~m}$ (see Figs. 3E and 3F). They form as the result of the inflation of the adjacent sectors into a rapidly cooled thin sector of the flow. They are partially filled with sandy material and frequently show an annular fracture at the rims of the hole, similar to the perimeter inflation cleft of the flat roof lava rise that contains the lava-rise pits (Fig. 6D).
Lava-rise ridges were defined by Whitehead and Stephenson (1998) as tumuli with a length/ width ratio $>10$. The axial ratios determined in the inflation ridges of the EPLF show values between 12 and 15, with some ratios being out of that range (up to 28). The average length of the ridges varies between 120 and $250 \mathrm{~m}$, the average width varies between 10 and $20 \mathrm{~m}$ and some isolated cases have shown extreme lengths of about $600 \mathrm{~m}$. Frequently, the longitudinal axes are curved (Fig. 6E) and in rare cases they present straight formats. As in the tumuli, the axial inflation clefts exhibit similar "Y" patterns that affect the total length of the structures, without being conditioned by the remarkable lengths they present. Usually, they are observed as isolated, although as with the tumuli, they can be exhibited in small clusters of parallel individuals (Fig. 6F).

Another type of structure that was generated by the mechanism of inflation and is possibly linked to the great longitudinal development that presents this flow corresponds to lava tubes. Depending on their size they can be differentiated into major or 

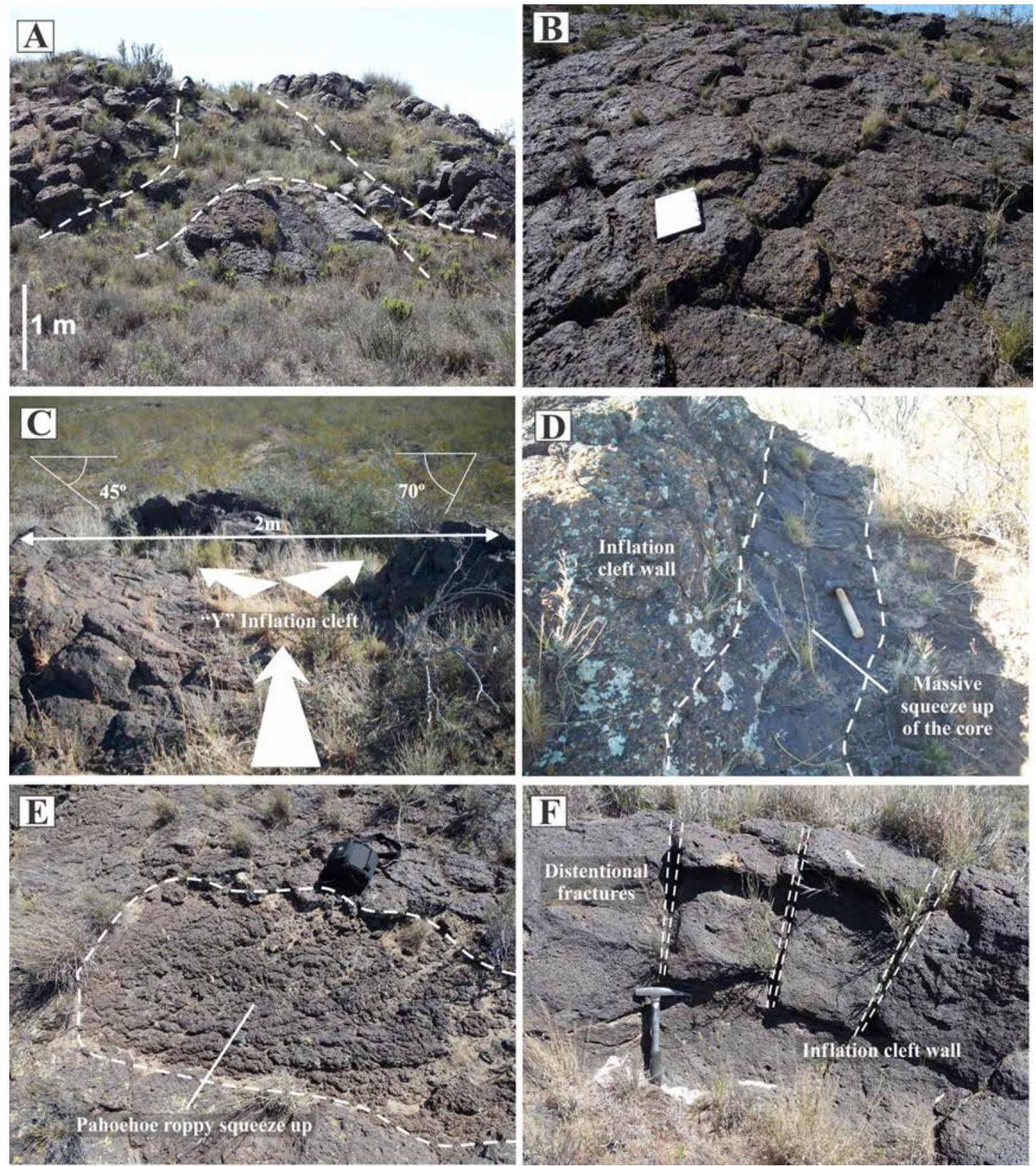

FIG. 5. Inflation structures located in the distal sector of the EPLF (site EP3 in Fig. 2). A. Tip of a tumulus crossed by a Y-shaped inflation cleft. B. External crust of a tumulus affected by polygonal joints; C. Typical Y-shaped geometry of an inflation cleft; D. Massive lava dike-like squeezed-up, injected into the inflation cleft. This occurs when the inflation fracture reaches up to the liquid core of the structure during the inflation process; E. Pahoehoe squeeze-up with ropy flow structure located in the roof of a tumulus; F. Fracture pattern of an inflation cleft wall as a consequence of the distention forces that were concentrated in upper sectors of the structure during the inflation process.

master tubes, secondary tubes and capillary tubes. The larger structures that feed the distal fronts of the lava flow are constructed from the convergence of networks of secondary tubes that formed during the cooling of the proximal sectors of the flow. Some of the lava tubes of the EPLF were inferred through 

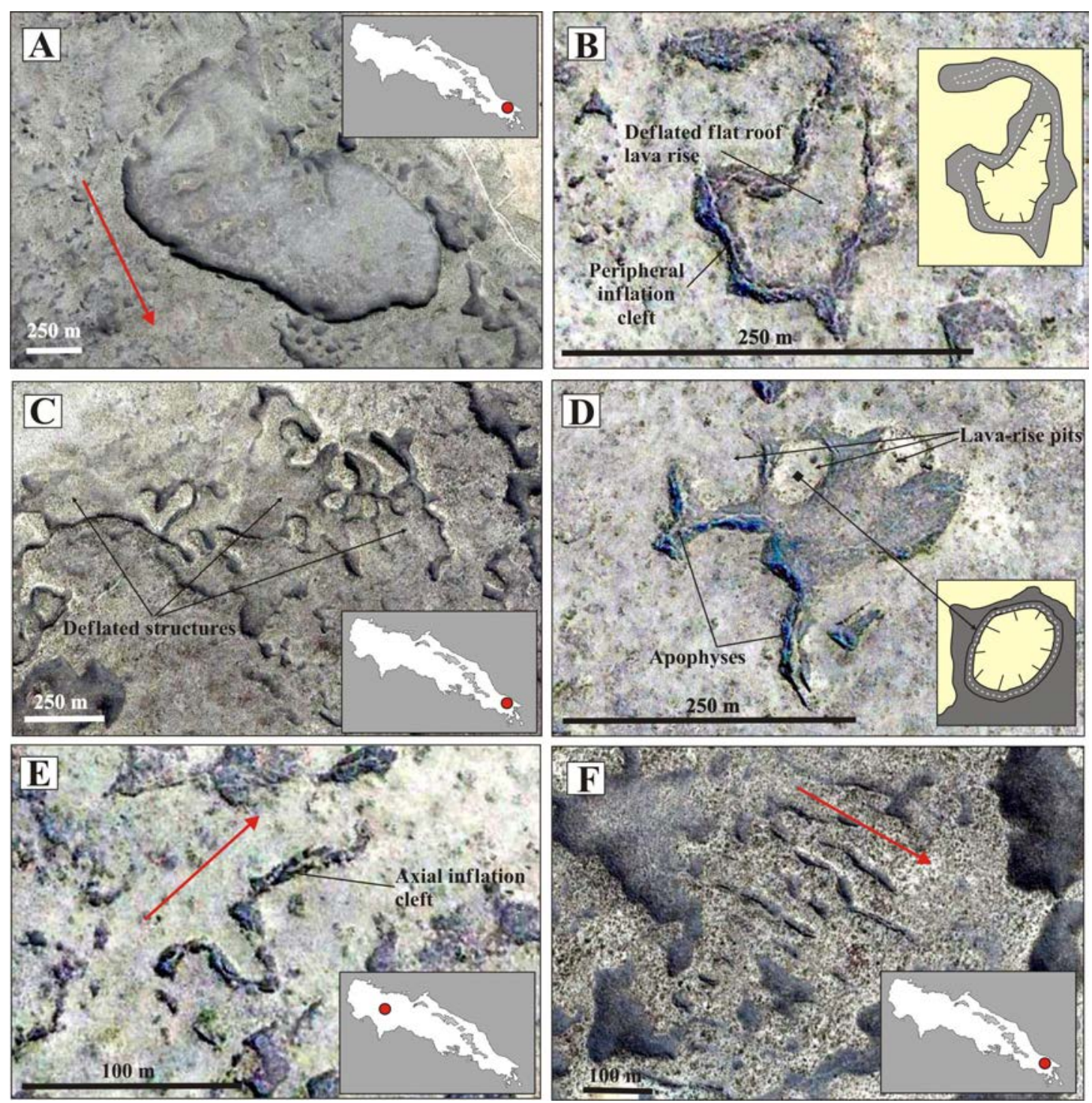

FIG. 6. Satellite imagery (Google Earth) of inflation structures located in the distal sector of the EPLF (site EP3), red dot in the inset indicates the image location in EPLF. The red arrows indicate the flow direction. A. Giant flat roof elevation which exhibits an elliptical geometry in aerial view. It exceeds $1500 \mathrm{~m}$ in length and has heights greater than $10 \mathrm{~m}$ with respect to the surrounding flow. It is the biggest lava rise that was surveyed in this flow; B. and C. Flat roof lava rises with deflation in its central sector. In figure B the peripheral inflation cleft that is generated in the structure rims during inflation is clearly observed; D. Lava-rise pits of sub-circular geometry, filled by sandy sediments and with annular fractures at their rims. The inflation ridges that take off the lava rise are known as apophyses and frequently link two or more of the lava rises; E. Markedly curved inflation ridge with axial inflation cleft; $\mathbf{F}$. Cluster of inflation ridges and tumuli with parallel arrangement.

the processing of satellite images via morphological evidence on the flow roof. Others were observed during the fieldwork as in the case of the lava tunnel known as "Cueva de Halada". It is a fully drained master tube located at $36^{\circ} 57^{\prime} \mathrm{S}$ and $68^{\circ} 05^{\prime} \mathrm{W}$, in the medial sector of the EPLF (Fig. 7A). Morphologically, it comprises a main gallery of arched roof that branches into three secondary galleries of shorter length. The total length of the tunnel is $369.50 \mathrm{~m}$, the maximum height is $2.20 \mathrm{~m}$ and the maximum 
width is $22.90 \mathrm{~m}$ (Figs. 7A and 7B) (Bertotto, 1996; Martínez, 1998). The entry of the cave is a small skylight of $0.60 \mathrm{~m}$ in diameter. The basalt that forms the tunnel roof shows a vesicular structure (amygdaloidal) that becomes more massive towards the walls (Fig. 7C). The inner roof of the tunnel may have an irregular structure (Fig. 7D) or is smooth with polygonal joints. It is covered by patches and small stalactites of carbonates (Fig. 7E) and in some sections it exhibits lava drops of up to $2 \mathrm{~cm}$.
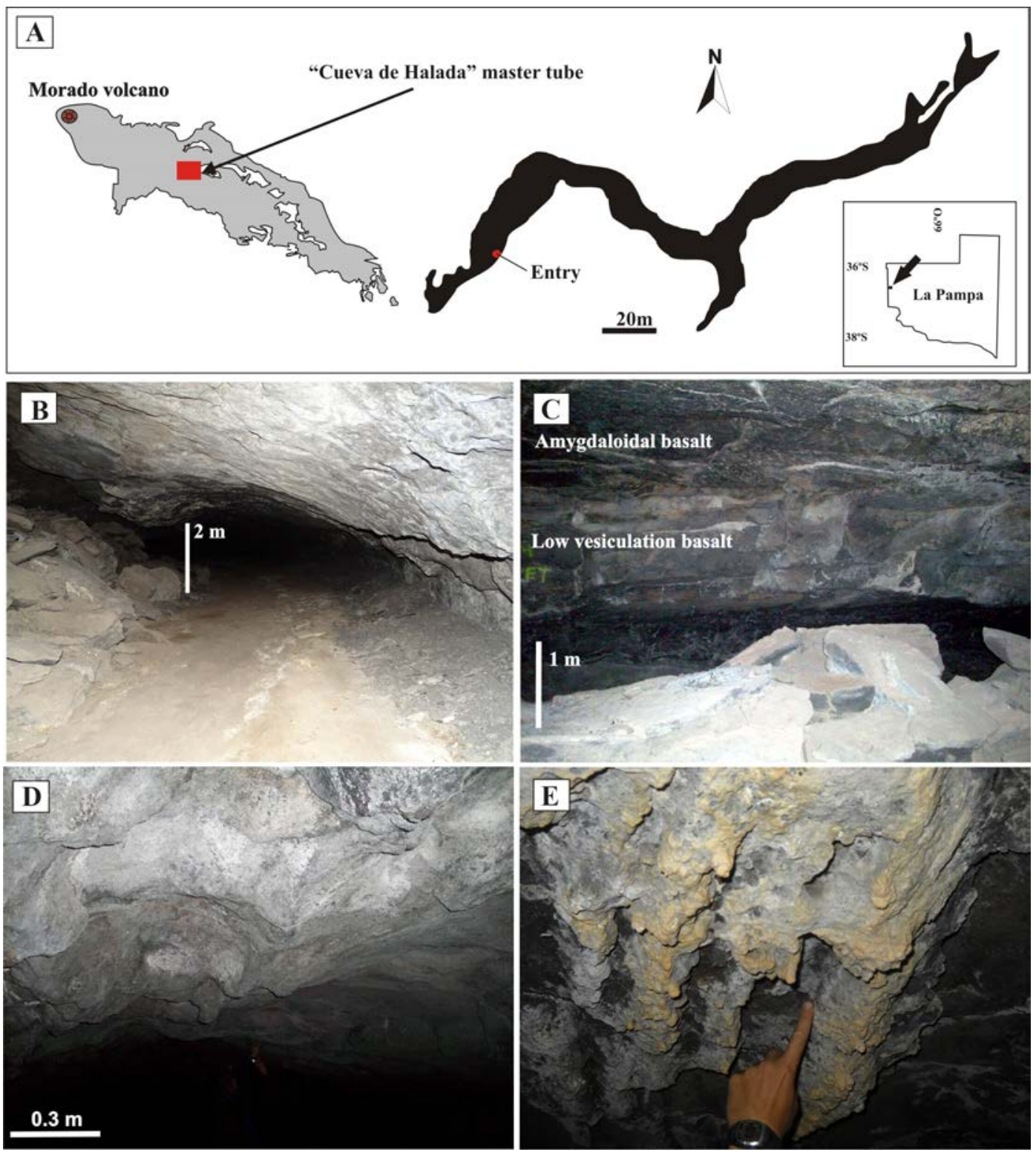

FIG. 7. Master lava tunnel "Cueva de Halada". Internal structure. A. Location of the "Cueva de Halada" in the EPLF (site EP2 in Fig. 2). The aerial view morphology and the speleometric data were taken from Bertotto (1996) and Martínez (1998); B. Cross-section of the tunnel sector below the access opening. This section presents the largest width of the entire structure and corresponds to the main gallery; C. Structure of walls and roof; D. Roof with irregular structure; E. Stalactites of the calcareous material that cover some section of the tunnel roof. 
According to the classification suggested by Calvari and Pinkerton (1999), based on the morphology of the lava tunnels, the "Cueva de Halada" tunnel exhibits characteristics of a simple and symmetrical tunnel, formed from the crust cooling around a stable and inflated flow. The detailed morphometric surveys carried out in the "Cueva de Halada" (Bertotto, 1996; Martínez, 1998) revealed that there are two sectors in which there are changes by up to $90^{\circ}$ in the general direction of the trajectory of the master gallery (Fig. 7E). The shape of the cross-section of the tunnel at several points shows certain asymmetry. This is interpreted as the result of differential lava accumulation due to local changes in the direction of the main path of the tunnel.

Another type of lava tube was observed in an area of inflation structures located about $27 \mathrm{~km}$ southeast of the "Cueva de Halada", in the distal sector of the EPLF (site EP3 in Fig. 2A). These are capillary tubes that display a centimetric scale and cross over the tumuli in which they are hosted (Fig. 8A and sketches). These features show crosssections of about $0.5 \mathrm{~m}$ in width and up to $0.25 \mathrm{~m}$ in height $\left(\sim 0.4 \mathrm{~m}^{2}\right)$ with a morphology that is characterized by an arched roof and slightly flat floor. The peripheral basalt surrounding the tubes shows a vesicular structure and frequently presents radial fractures that converge towards the center of the tunnel. Small-scale lava tubes were also found in a field of inflation structures located near the Morado volcano, hosted by pahoehoe fingers (Fig. 8B and sketches).

Other morphology aspects that reveal the existence of lava tubes inside the flow include: tumuli alignments, the development of extremely long inflation ridges (Fig. 9A) and the apophyses that join and feed flat roof lava rises. It is interpreted that the presence of these structures indicates that tubes where not drainage tubes, keeping filled with the flow that moved inside as a consequence of collapse or blocking of a segment of the tunnel. Large-scale channel-like reliefs observed in some sectors of the flow surface were interpreted as drainage master tubes where roof has collapsed (Fig. 9B).

The kipukas and pressure ridges are not related to the inflation process. The kipukas are the product of the presence of positive substrate relief that hindered the flow path. The wind activity eroded the substrate rocks and generated a depressed relief that constitute small endorheic drainage depressions.
Shallow ephemeral water courses or springs flow to these depressions and can form salt flats (Fig. 10A). The pressure ridges are long and narrow individual features that result from lateral pressures within the flow. The best example of a pressure ridge was observed in the distal sector of the EPLF, where the main flow comes into the depression of Bardas Bayas and joins with the secondary northern branch, colliding with it. In this area, the pressure between both flows generated a ridge of $12.6 \mathrm{~km}$ in length and up to $100 \mathrm{~m}$ in width, with variable heights of between 2 and $4 \mathrm{~m}$ (Fig. 10B).

\subsection{Petrology features}

As mentioned above, El Puesto lava flow mainly advanced over a basaltic lava substrate while the northern branch that circulated through the Bardas Bayas depression, mobilized over CretaceousPaleogene calcareous rocks. In general terms, the basalt samples collected from the EPLF presents porphyritic to glomeruloporphiritic texture with intergranular groundmass. The phenocrystalline fraction is represented by olivine and plagioclase. Olivine exhibits mostly euhedral to subhedral individuals showing prisms or short columns with hexagonal to pseudo-hexagonal sections, being granular in the microlithic phases. The olivine phenocrysts reach sizes of up to $1 \mathrm{~mm}$, present abundances of 7 to $10 \mathrm{vol} . \%$ and they are generally fresh. Plagioclase occurs in crystals with uniform sizes averaging $0.6 \mathrm{~mm}$. It is observed in groups oriented in oblique directions to each other, resulting in a felted microtexture. In general, plagioclase exhibits subhedral grains with polysynthetic twins and constitutes the more abundant mineral phase ( $\approx 60-80$ vol.\%). Occasionally, it shows tabular individuals up to 1 $\mathrm{mm}$, with screened textures. Clinopyroxene is mostly microlithic and interstitial, and abounds in approx. 10 vol. $\%$, surpassing the olivine at this scale. It is anhedral (granular) and in few cases it reaches sizes of up to $0.5 \mathrm{~mm}$. The opaque minerals do not exceed 2 vol.\% in abundance, occupying the interstices with olivine and clinopyroxene and generally exhibiting anhedral (granular) to subhedral (prismatic) forms.

In table 2 is presented the major elements composition of an alkaline basalt of EPLF (MD174, lat/long: $36^{\circ} 58^{\prime} \mathrm{S} / 68^{\circ} 8^{\prime} \mathrm{W}$, Fig $2 \mathrm{~A}$ ). The viscosity of EPLF has been calculated from major elements composition, using the algorithm of Shaw (1972) at 

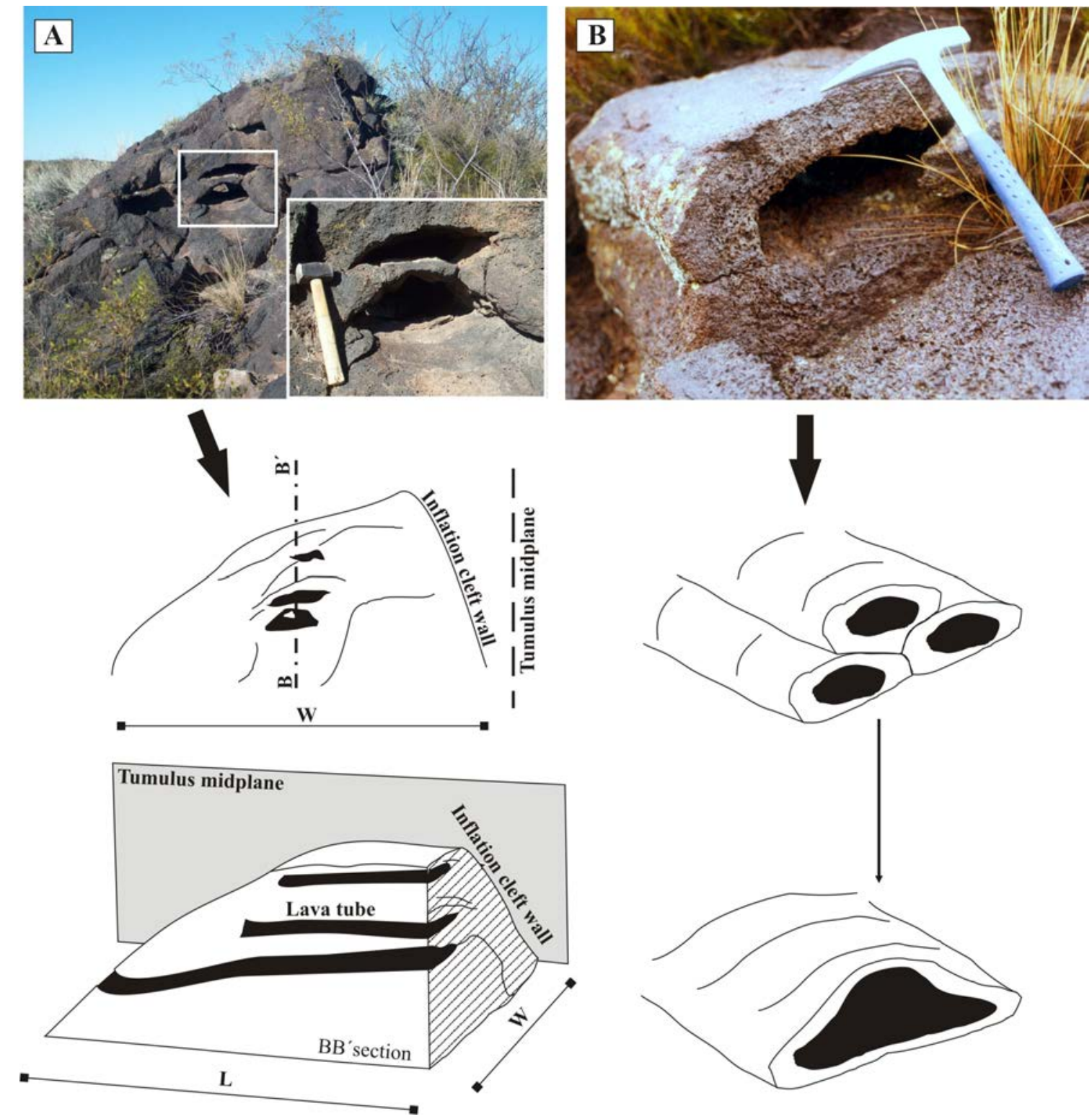

FIG. 8. Inflation structures. A. Centimeter-scale lava tubes extending longitudinally through the body of a tumulus located in a field of inflation structures in the distal portion of the EPLF; B. Capillary lava tube hosted in pahoehoe finger, near the eruptive center. The diagram shows a stacking of pahoehoe fingers with development of capillary tubes which can evolve into secondary tunnels and then to master tunnels by eliminating the partitions that separate them, due to the erosion of the flow that circulates inside (Wentworth and Macdonald, 1953; Greeley, 1987).

1,100 and $1,200^{\circ} \mathrm{C}$, assuming voids-free magma and taking into account an average volume of phenocrysts of $8 \%$ with average size of $0.5 \mathrm{~mm}$. For this lava flow, values for effective viscosity $\left(\eta^{\prime}\right)$ were obtained in the range between 1,550 and $483 \mathrm{~Pa} \mathrm{~s}$, whereas values for lava glass viscosity $(\eta)$ were obtained in the range between 28 and $8.7 \mathrm{~Pa}$ s. For basaltic melts $\left(\mathrm{SiO}_{2}=49-51 \mathrm{wt} . \%\right)$, with liquid temperatures ranging between 1,050 and $1,200{ }^{\circ} \mathrm{C}$ and phenocrysts volume between 0 and $25 \%$, the viscosity has been estimated to range from 10 to $10^{3} \mathrm{~Pa}$ s (Scarfe, 1973 ) and from $10^{2}$ to $10^{3} \mathrm{~Pa}$ s (Keszthelyi and 

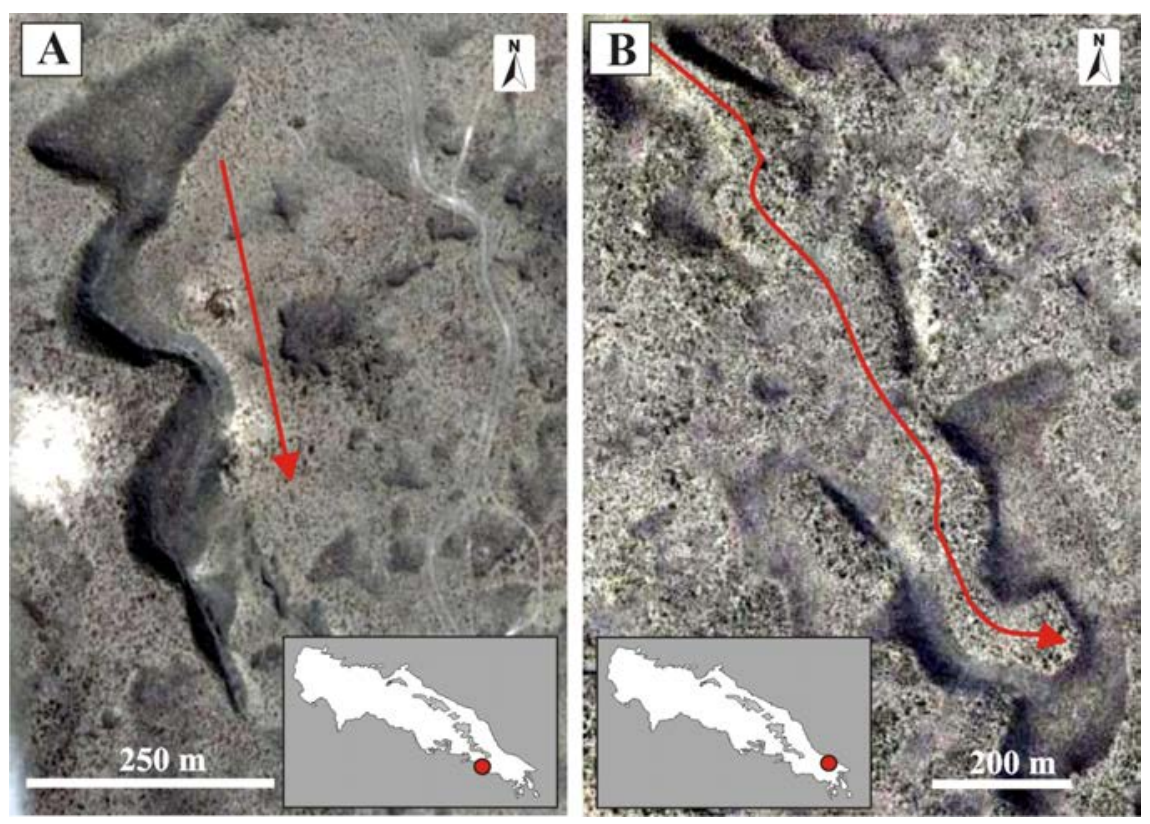

FIG. 9. Satellite imagery (Google Earth) showing two different structures from which the presence of lava tunnels of important dimensions is inferred. A. Sinuous and extremely long inflation ridge $(670 \mathrm{~m})$; B. Large-scale channel-like relief interpreted as a drainage master tunnel which roof has collapsed. This relief extends several hundred meters towards the northwest. The local direction of the flows movement is indicated with red arrows and the images location is shown by the red dots in the EPLF.

TABLE 2. MAJOR ELEMENTS DATAAND NORMATIVE MINERALS OF MD 174 SAMPLE FROM THE EL PUESTO LAVA FLOW.

\begin{tabular}{lc}
\hline Sample & MD174 \\
\hline $\mathrm{SiO}_{2}$ & 47.64 \\
$\mathrm{TiO}_{2}$ & 1.66 \\
$\mathrm{Al}_{2} \mathrm{O}_{3}$ & 14.24 \\
$\mathrm{Fe}_{2} \mathrm{O}_{3}$ & 12.85 \\
$\mathrm{MnO}$ & 0.15 \\
$\mathrm{MgO}$ & 10.60 \\
$\mathrm{CaO}$ & 8.49 \\
$\mathrm{Na}_{2} \mathrm{O}$ & 3.23 \\
$\mathrm{~K}_{2} \mathrm{O}$ & 0.64 \\
$\mathrm{P}_{2} \mathrm{O}_{5}$ & 0.29 \\
$\mathrm{Total}(w t \%)$ & 99.78 \\
\hline $\mathrm{Normative} \mathrm{minerals}$ & \\
\hline $\mathrm{Or}$ & 3.78 \\
$\mathrm{Ab}$ & 27.01 \\
$\mathrm{An}$ & 22.5 \\
$\mathrm{Ne}$ & 0.21 \\
$\mathrm{Di}$ & 14.44 \\
$\mathrm{Ol}$ & 24.52 \\
$\mathrm{Mt}$ & 3.76 \\
$\mathrm{Il}$ & 3.16 \\
$\mathrm{Ap}$ & 0.63 \\
\hline
\end{tabular}

Analyzed at Università di Modena e Reggio Emilia (Italy), XRF method as Franzini et al. (1975).
Pieri, 1993; Crisp et al., 1994; Thordarson, 1995; Ho and Cashman, 1997). Effective viscosity values of EPLF could be considerated inside the range of basalt melt viscosities, but glass viscosities show very low values with respect to the values obtained experimentally.

\section{Discussion}

The EPLF comprises a lava flow formed by a single flow unit that reached thicknesses of up to $5 \mathrm{~m}$, subsequently developing local inflation structures with similar thicknesses. The lava flow moved southeast over a substrate with a slope of up to $0.5^{\circ}$, in which it encountered some previous obstacles, such as small pyroclastic cones in its lower half section and other positive reliefs, which generated kipukas. A segment of the northern sector was channeled in the depression of Bardas Bayas while the main body had no relief confinement, which is evidenced by some secondary spills to the south and into the mentioned depression. The development of a P-type pahoehoe flow is commonly associated to the following aspects: 1 . Low-angle slopes $\left(<2^{\circ}\right)$, that allow slow and discontinuous displacements 

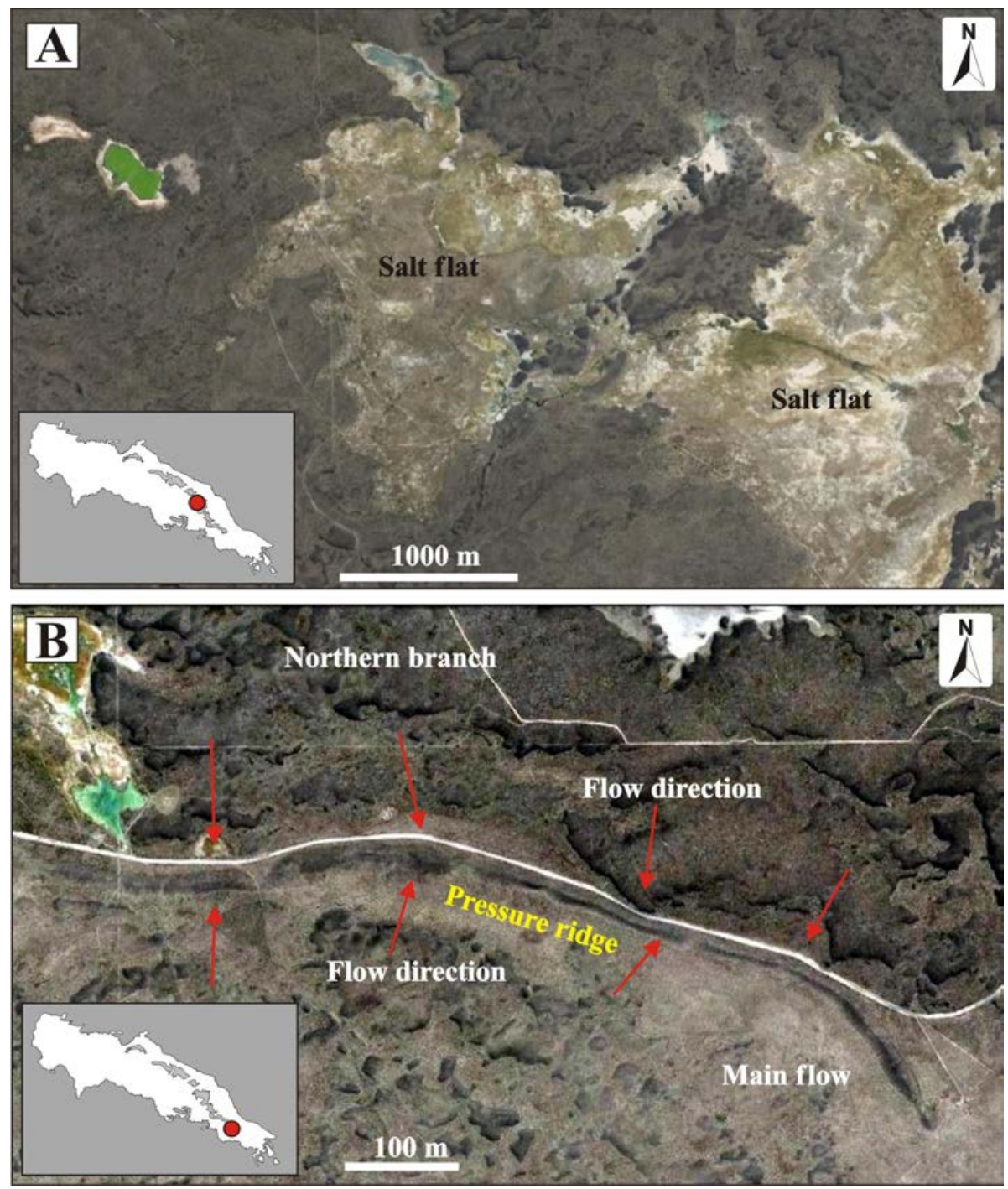

FIG. 10. Other landforms originated during the emplacement of the El Puesto lava flow. A. Salt flats installed in depressed reliefs developed inside the kipukas; B. Pressure ridge generated by the collision between the main body of the flow and the northern branch, in their distal portions. The structure was formed by lateral compression and not by inflation. The local directions of movement of the flows are indicated with red arrows. Red dots in the insets show the image location in the EPLF.

through the generation and lateral coalescence of lobes in the front of the flow, 2. thermal insulation of the inner liquid core of the lobes by development of an external cooling crust, 3. development of capillary, secondary and master tubes through which the lava flows to the distal sectors, and 4. inflation process with development of localized structures. The inflation rates and the local or regional extension of this process were conditioned mainly by the lava supply of the source (Hon et al., 1994; Self et al.,
1998). The landforms which developed during the inflation are distributed throughout the surface of the flow and frequently they are observed forming belts with a high concentration of structures that seem to converge to a single main belt (Figs. 11 A and 11B). These features were interpreted as internal preferential lava pathways (secondary tubes) within the main lava body. Inflation structures generally have their longitudinal axes disposed according to the belt direction. 
In the distal sectors of the flow, some landforms such as flat roof lava rises and lava-rise ridges exhibit better development, while the tumuli show clusters of 15, 20 or more individuals. It is inferred that this aspect may be a consequence of the abrupt slope change observed in the last $20 \mathrm{~km}$ of the flow, where it reduces from $0.5^{\circ}$ to $0.15^{\circ}$ in the main lava flow and from $0.35^{\circ}$ to $0.11^{\circ}$ in the northern branch of Bardas Bayas. In addition, the height difference between the eruptive center and the terminal portion of the flow exceeds $400 \mathrm{~m}$ which possibly maintained an increasing overpressure towards the terminal portions of the flow, enough to keep a sustained inflation process in these sectors (Rossi, 1996; Rossi and Gudmunsson, 1996).

From their morphological characteristics, the described tumuli of the EPLF (see Section 3.3) are classified within the flow-lobe tumuli category as proposed by Rossi and Gudmundsson (1996) from their survey of numerous inflation structures in Icelandic lava fields. According to their observations, flow lobe tumuli are common in the middle and distal sectors of the pahoehoe lava fields. They have low dip flanks and exhibit small volume squeeze ups that are restricted to the limits of the axial fracture. The internal distribution of vesicles is similar to that of P-type flows. For its formation, low rates of lava supply from the source are necessary, which allows a better development of the external crust to be able to hold up the incoming lava without fracturing for a longer period of time. These authors noted that the flow-lobe tumuli described in these lava flows are practically absent in those sectors where master lava tubes are located. In the flow of the present
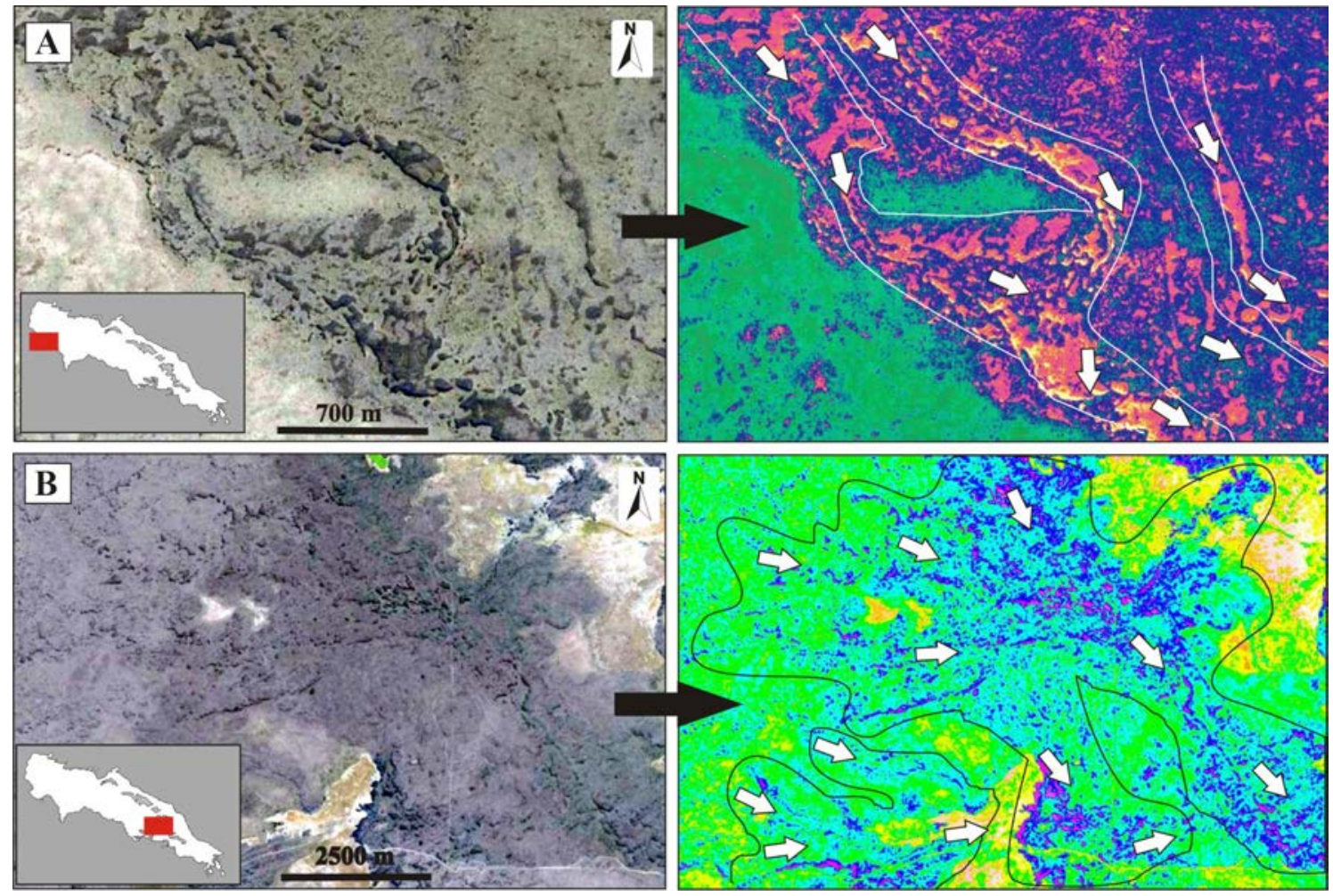

FIG. 11. Satellite imagery (Google Earth) processed with image processing software in which are highlighted the belts with high concentration of inflation structures within the flow. The first image A. corresponds to the lower-half section of the EPLF; the magenta and yellow colors represent the inflated structures. The second image B. belongs to the distal portion of the flow; the blue and violet colors represent the inflated structures while the green color corresponds to the flow sectors without processes of local inflation. In both, the convergence of smaller belts into one belt of greater development is observed. Red squares in the insets indicate the image location in the EPLF. 

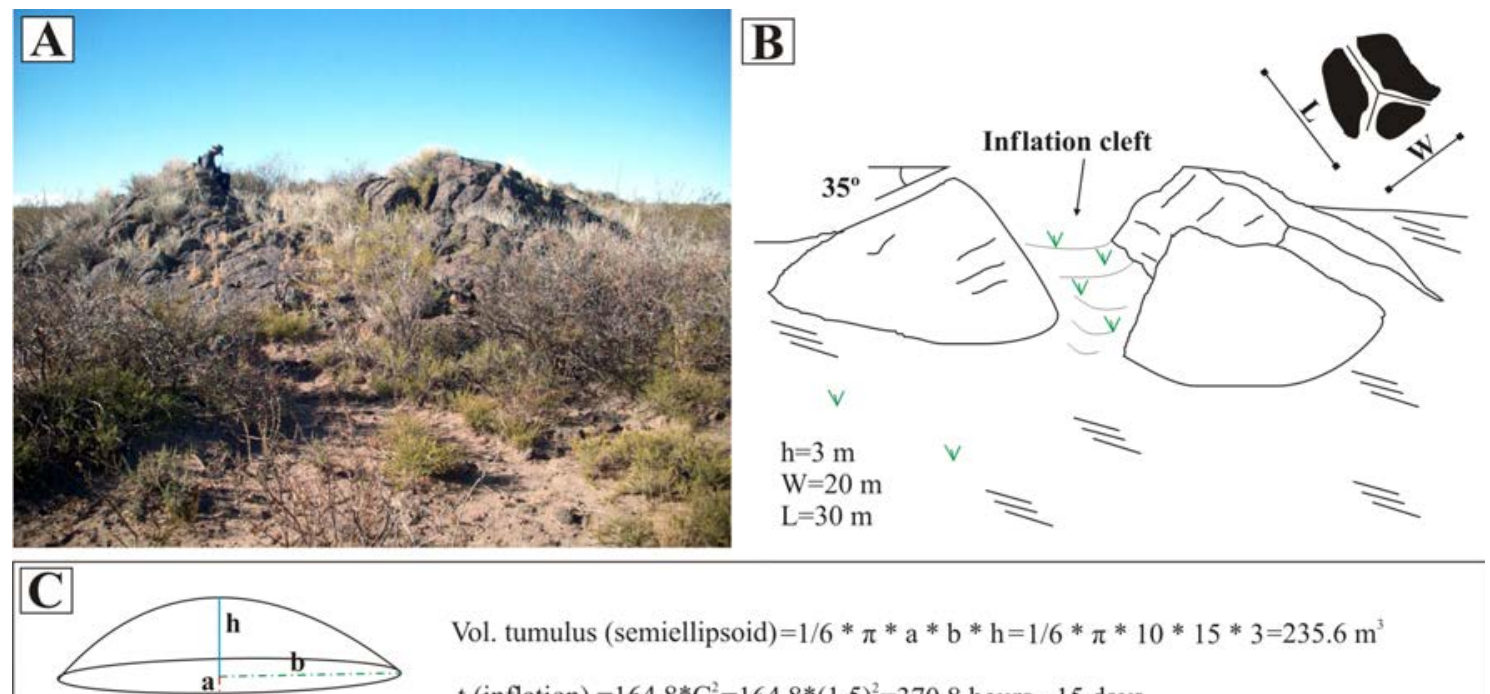

Vol. tumulus (semiellipsoid) $=1 / 6 * \pi * \mathrm{a} * \mathrm{~b} * \mathrm{~h}=1 / 6 * \pi * 10 * 15 * 3=235.6 \mathrm{~m}^{3}$

$\mathrm{a}=1 / 2 \mathrm{~W} ; \mathrm{b}=1 / 2 \mathrm{~L}$

$\mathrm{t}$ (inflation) $=164.8 * \mathrm{C}^{2}=164.8 *(1.5)^{2}=370.8$ hours $\sim 15$ days

FIG. 12. Volume and time of inflation calculus of a typical tumulus of El Puesto lava flow. A. Field image of the parameterized structure; B. Measured parameters of the tumulus; $\mathbf{C}$. The volume of the tumulus was determined by approximating its geometric shape to that of a semi-ellipsoid. The inflation time ( $\mathrm{t}$ ) is calculated according with the algorithm of Hon et al. (1994).

study this situation is fulfilled in the sectors nearby the "Cueva de Halada" lava tube and for the sites where landforms were observed and interpreted as drained and collapsed tunnels.

We have made an estimation of the rate of the lava supply required to inflate an average tumulus of the EPLF located in a distal position (site EP3, Fig 2A). The algorithm of Hon et al. (1994), which was modeled in Hawaiian lava flows for the estimation of the time of inflation, was used. The measured structure has a length of $30 \mathrm{~m}(\mathrm{~L})$, a height of $3 \mathrm{~m}(\mathrm{~h})$ and a basal width of approximately $20 \mathrm{~m}(\mathrm{~W})$ (Figs. 12A and 12B). The thickness of its upper vesicular crust is $1.5 \mathrm{~m}(\mathrm{C})$ and was measured vertically in the wall of the axial fracture. For the calculation of the volume of the structure, its geometry was approximated to the geometry of a semi-ellipsoid (Fig. 12C).

Assuming a sustained effusion of lava and a uniform daily inflation rate, the value of the lava supply rate for this average tumulus was $1.8 \times 10^{-4} \mathrm{~m}^{3} / \mathrm{s}$ during 15 days. These values are consistent with those obtained from Icelandic lava fields by Rossi and Gudmunsson (1996), who noted that flow-lobe tumuli formed in those fields under very low effusion rates of between $10^{-2}$ and $10^{-5} \mathrm{~m}^{3} / \mathrm{s}$ in a time range of between 4 and 21 days.
The high density of inflation structures resulted in a hummocky flow throughout the EPLF area. The formation process of these structures, including the lava tunnels, through which they are fed, requires low to moderate effusion rates for their development (Hallworth et al., 1987; Rossi and Gudmunsson, 1996). From this last concept, the structural characteristics of the flow and its remarkable length $(70 \mathrm{~km})$ show a continuous and sustained supply of lava over a very long time period. The flow could be high at first, giving rise to the formation of a sheet flow of great lateral extension. Subsequently, fluctuations in effusion rates could favor the development of internal pathways (tubes) that delivered lava to the distal fronts, generating both inflation and deflation processes which extended throughout the lava flow.

\section{Conclusions}

The El Puesto lava flow is a single basaltic flow of $0.200 \pm 0.027$ Ma located in the southern-central Payenia Volcanic Province which was extruded from the Morado volcano.

The lava flow presents a longitudinal development of $70 \mathrm{~km}$ and a coverage area of $856 \mathrm{~km}^{2}$. A minimum volume of $4 \mathrm{~km}^{3}$ of lava was estimated for this flow. 
The tumuli represent up to $85 \%$ of the structures originated by local accumulations of lava and to a lesser extent appear inflation ridges and flat roof lava rises. The tumuli of the EPLF classify in the category of flow-lobe tumuli. Lava-rise pits are frequently observed in flat-roof lava rises and represent sectors of these structures that remained uninflated. Axial Y-shaped fractures and annular clefts are the common feature of all inflation structures and are formed by localized distension associated with the inflation process.

The slope on which the EPLF moved was up to $0.5^{\circ} \mathrm{SE}$ which allowed slow displacements and lateral coalescence of lobes at the flow front and the development of an external rigid crust that allowed the thermal insulation of liquid internal core. The heterogeneous cooling of the interior of the lava flow led to the development of lava tubes simultaneously with the lobe inflation process. The "Cueva de Halada" represents a simple and largely symmetrical master tunnel, formed from the cooling of the crust around a stable inflated flow. As it is a drained tunnel, there are no landforms of accumulation linked to it. Tumuli alignments, inflation ridges, and apophyses joining flat roof lava rises reveal the existence of larger tunnels within the flow, which may have remained filled by the internal flow.

The occurrence of belts with high concentration of inflation structures are interpreted as the result of a network of secondary internal flows within the main lava body.

The major development of flat roof lava rises and inflation ridge in the distal portions of the flow is a consequence of the abrupt slope change in the distal sector and the increasing overpressure towards the terminal portions of the flow, as a consequence of a lava supply sustained over time and the marked elevation difference between the effusion center and the distal portion of the flow $(\sim 400 \mathrm{~m})$.

It was inferred that a high, continuous and sustained supply of low viscosity lava initially generated a sheet flow of great lateral extension. The reduction in effusion rates could then favor the development of tubes that carried lava to the distal fronts, generating localized inflation and deflation phenomena throughout the lava flow.

The flow advance through lateral coalescence and lobe inflation with the subsequent formation of lava tubes, and the low to moderate lava viscosity $(\eta=28$ 8.7 $\mathrm{Pa} \mathrm{s}, \eta '=1.550-483 \mathrm{~Pa} \mathrm{~s}$ ) were the determining factors in the emplacement of the El Puesto lava flow, which traveled a distance of $70 \mathrm{~km}$ from its effusion center.

\section{Acknowledgments}

This research was supported by UNLPam (PI3G) and CONICET (PIO2015-12CO) grants. We acknowledge help during XRF analysis of M. Mazzucchelli and help with the English language of this paper by M. Copley. The authors acknowledge Venera R. May and W. Vivallo for their constructive comments and editorial work that helped to improve the manuscript.

\section{References}

Agashe, L.V.; Gupte, R.B. 1971. Mode of eruption of the Deccan Traps basalts. Bulletin of Volcanology 35: 591-601.

Atkinson, A.; Atkinson, V. 1995. Undara Volcano and its lava tubes: a geological wonder of Australia in Undara Volcanic National Park, North Queensland. Vernon and Anne Atkinson: 96 p. Brisbane.

Aubele, J.C.; Crumpler, L.S.; Elston, W.E. 1988. Vesicle zonation and vertical structure of basalt flows. Journal of Volcanology and Geothermal Research 35: 349-374.

Bermúdez, A.; Delpino, D.; Frey, F.; Saal, A. 1993. Los basaltos de retroarco extraandinos. In Geología y Recursos Naturales de Mendoza, Relatorio (Ramos, V.A.; editor). Congreso Geológico Argentino, No. 12 y Congreso de Exploración de Hidrocarburos, Asociación Geológica Argentina, No. 2: 161-173. Buenos Aires.

Bernardi, M.I. 2016. Petrología y volcanología de los flujos basálticos neógeno-cuaternarios del retroarco extraandino entre los $36^{\circ}$ y $37^{\circ} 30^{\prime} \mathrm{LS}$, provincias de Mendoza y La Pampa, Argentina. Ph.D. Thesis (Unpublished), Universidad Nacional de Córdoba: $353 \mathrm{p}$.

Bernardi, M.I.; Bertotto, G.W.; Jalowitzki, T.L.R.; Orihashi, Y.; Ponce, A. 2015. Emplacement history and inflation evidences of a long basaltic lava flow located in Southern Payenia Volcanic Province, Argentina. Journal of Volcanology and Geothermal Research 293: 46-56.

Bernardi, M.I.; Bertotto, G.W.; Ponce, A.D. 2016. Estructuras de segregación vesiculadas alojadas en coladas basálticas pahoehoe de Payenia, provincias de Mendoza y La Pampa, Argentina. Aspectos morfogenéticos y petrográficos. Revista de la Asociación Geológica Argentina 73 (1): 50-63. 
Bernardi, M.I.; Bertotto, G.W.; Ponce,A.D. 2018. Procesos de diferenciación in situ en coladas basálticas pliopleistocenas del sur de Payenia, provincias de Mendoza y La Pampa. Revista de la Asociación Geológica Argentina 75 (1): 152-169.

Bertotto, G.W. 1996. Morfología del túnel lávico cenozoico "Cueva de Halada". Departamento Puelén, provincia de La Pampa. In Jornadas Pampeanas de Ciencias Naturales, No. 6, COPROCNA: 13-15. Santa Rosa.

Bertotto, G.W.2003. Evolución geológica y petrológica de los conos basálticos cenozoicos portadores de xenolitos ultramáficos del margen oriental de la Provincia basáltica Andino-Cuyana, provincias de La Pampa y Mendoza. Ph.D. Thesis (Unpublished), Universidad Nacional de La Plata: 186 p.

Bertotto, G.W.; Bjerg, E.A.; Cingolani, C.A. 2006. Hawaiian and Strombolian style monogenetic volcanism in the extra-Andean domain of central-west Argentina. Journal of Volcanology and Gethermal Research 158: 430-444.

Bertotto, G.W.; Cingolani, C.A.; Bjerg, E.A. 2009. Geochemical variations in Cenozoic back-arc basalts at the border of La Pampa and Mendoza provinces, Argentina. Journal of South American Earth Sciences 28: 360-373.

Calvari, S.; Pinkerton, H. 1999. Lava tube morphology on Etna and evidence for lava flow emplacement mechanisms. Journal of Volcanology and Geothermal Research 90: 263-280.

Cashman, K.V.; Kauahikaua, J.P. 1997. Reevaluation of vesicle distributions in basaltic lava flows. Geology 25: 419-22.

Crisp, J.; Cashman, K.V.; Bonini, J.A.; Hougen, S.B.; Pieri, D.C. 1994. Crystallization history of the 1984 Mauna Loa lava flow. Journal of Geophysical Research: Solid Earth (1978-2012) 99 (B4): 7177-7198.

Dyhr, C.T.; Holm, P.M.; Llambías, E.J.; Scherstén, A. 2013. Subduction controls on Miocene back-arc lavas from Sierra de Huantraico and La Matancilla and new ${ }^{40} \mathrm{Ar} /{ }^{39} \mathrm{Ar}$ dating from the Mendoza Region, Argentina. Lithos 179: 67-83.

Espanon, V.R.; Chivas, A.R.; Phillips, D.; Matchan, E.L.; Dosseto, A. 2014. Geochronological, morphometric and geochemical constraints on the Pampas Onduladas long basaltic flow (Payún Matrú Volcanic Field, Mendoza, Argentina). Journal of Volcanology and Geothermal Research 289: 114-129.

Folguera, A.; Naranjo, J.A.; Orihashi, Y.; Sumino, H.; Nagao, K.; Polanco, E.; Ramos, V.A. 2009. Retroarc volcanism in the northern San Rafael block $\left(34^{\circ}-35^{\circ} 30^{\prime} \mathrm{S}\right)$, southern-Central Andes: occurrence, age, and tectonic setting. Journal of Volcanology and Gethermal Research 186: 169-185.

Franzini, M.; Leoni, L.; Saitta, M. 1975. Revisione di una metodologia analitica per fluorescenza-X, basata sulla correzione completa degli effetti di matrice. Rendiconti della Societa Italiana di Mineralogia e Petrologia 31: 365-379.

Germa, A.; Quidelleur, X.; Gillot, P.Y.; Tchilinguirian, P. 2010. Volcanic evolution of the back-arc Pleistocene Payún Matru Volcanic Field (Argentina). Journal of South American Earth Sciences 29: 717-730.

González Díaz, E.F. 1979. Descripción Geológica de la Hoja 31d, la Matancilla, provincia de Mendoza. Servicio Geológico Nacional, Boletín 173: 96 p. Buenos Aires.

Greeley, R. 1987. The role of lava tubes in Hawaiian volcanoes. U.S. Geological Survey Professional Paper 1350: 1589-1602.

Groeber, P. 1946. Observaciones Geológicas a lo largo del Meridiano $70^{\circ}$. 1-Hoja Chos Malal. Sociedad Geológica Argentina, Revista 1: 177-208.

Gudnason, J.; Holm, P.M.; Søager, N.; Llambías, E.J. 2012. Geochronology of the late Pliocene to Recent volcanic activity in the Payenia back-arc volcanic province, Mendoza Argentina. Journal of South America Earth Sciences 37: 191-201.

Halldorsson, S.A.; Oskarsson, N.; Gronvold, K.; Sigurdsson, G.; Sverrisdottir, G.; Steinthorsson, S. 2008. Isotopic-heterogeneity of the Thjorsa lavaimplications for mantle sources and crustal processes within the Eastern Rift Zone, Iceland. Chemical Geology 255 (1-3): 305-316.

Hallworth, M.A.; Huppert, H.E.; Sparks, R.S.J. 1987. Lava Flows. Modern Geology 11: 93-107.

Harris, A.J.L.; Dehn, J.; Calvari, S. 2007. Lava effusion rate definition and measurement: a review. Bulletin of Volcanology 70: 1-22.

Hjartarson, A. 1988. The Thjorsa lava the largest Holocene lava flow on earth. Natturufraedingurinn 58: 1-16.

Ho,A.M.; Cashman, K.V. 1997. Temperature constraints on the Ginkgo flow of the Columbia River Basalt Group. Geology 25: 403-406.

Hoblitt, R.P.; Orr, T.R.; Heliker, C.; Denlinger, R.P.; Hon, K.; Cervelli, P.F. 2012. Inflation rates, rifts, and bands in a pahoehoe sheet flow. Geosphere 8: 179-195.

Hon, K.; Kauahikaua, J.; Denlinger, R.; Mackay, K. 1994. Emplacement and inflation of pahoehoe sheet flows: Observations and measurements of active lava flows on Kilauea Volcano, Hawaii. Geological Society of America Bulletin 106: 351-370. 
Inbar, M.; Risso, C. 2001. A morphological and morphometric analysis of a high density cinder cone volcanic field-Payun Matru, south-central Andes, Argentina. Zeitschrift für Geomorphologie 45: 321343.

Kay, S.M. 2002. Magmatic sources, tectonic setting and causes of Tertiary to Recent Patagonian plateau magmatism ( $36^{\circ} \mathrm{S}$ to $52^{\circ} \mathrm{S}$ latitude). In Congreso Geológico Argentino, No 15, Actas 3: 95-100. El Calafate.

Kay, S.M.; Gorring, M.; Ramos, V. 2004. Magmatic sources, setting and causes of Eocene to Recent Patagonian plateau magmatism $\left(36^{\circ} \mathrm{S}\right.$ to $52^{\circ} \mathrm{S}$ latitude). Revista de laAsociación Geológica Argentina 59 (4): 556-568.

Kay, S.M.; Burns, W.M.; Copeland, P.; Mancilla, O. 2006. Upper Cretaceous to Holocene magmatism and evidence for transient Miocene shallowing of the Andean subduction zone under the northern Neuquén Basin. Geological Society of America, Special Papers 407: 19-60.

Keszthelyi, L.P.; Pieri, D.C. 1993. Emplacement of the 75-km-long Carrizozo lava flow field, south-central New Mexico. Journal of Volcanology and Geothermal Research 59: 59-75.

Keszthelyi, L.; Denlinger, R. 1996. The initial cooling of pahoehoeflow lobes. Bulletin of Volcanology 58:5-18.

Keszthelyi, L.; Self, S.; Thordarson, T. 1999. Application of recent studies on the emplacement of basaltic lava flows to the Deccan Traps. In Deccan Volcanic Province (Subbarao, K.V.; editor). Memoir Geological Society of India: 43: 485-520.

Llambías, E.J. 1966. Geología y petrografía del volcán Payún Matrú. Acta Geológica Liloana 7: 256-310.

Manga, M. 1996. Waves of bubbles in basaltic magmas and lavas. Journal of Geophysical Research 101: 17457-17465.

Marchetti, D.W.; Hynek, S.A.; Cerling, T.E. 2014. Cosmogenic $3 \mathrm{He}$ exposure ages of basalt flows in the northwestern Payún Matru volcanic field, Mendoza Province, Argentina. Quaternary Geochronology 19: $67-75$.

Martínez, O.N. 1998. Descripción topográfica y geológica de la caverna Halada y su entorno, provincia de La Pampa. Revista Salamanca 10, Grupo Espeleológico Argentino. Buenos Aires.

May, V.R.; Chivas, A.R.; Dosseto,A.; Honda, M.; Matchan, E.L.; Phillips, D.; Price, D.M. 2018. Quaternary volcanic evolution in the continental back-arc of southern Mendoza, Argentina. Journal of South American Earth Sciences 84: 88-103.
Mazzarini, F.; Fornaciai, A.; Bistacchi, A.; Pasquarè, F.A. 2008. Fissural volcanism, polygenetic volcanic fields, and crustal thickness in the Payen Volcanic Complex on the central Andes foreland (Mendoza, Argentina). Geochemistry, Geophysics, Geosystems 9 (9): Q09002.

McMillan, K.; Long, P.E.; Cross, R.C. 1989. Vesiculation in Columbia River basalts. In Volcanism and Tectonism in the Columbia River Flood-Basalt Province (Reidel, S.P.; Hooper, P.R.; editors). Geological Society of America, Special Paper 239: 157-167.

Nagao, K.; Ogata, A.; Miura, Y.; Matsuda, J.; Akimoto, S. 1991. Highly reproducible 13 and $17 \mathrm{ka} \mathrm{K-Ar}$ ages of two volcanic rocks. Geochemical Journal 25:447-451.

Núñez, E. 1976. Descripción geológica de la Hoja 31e, Chical Co, provincias de Mendoza y La Pampa. Dirección Nacional de Geología y Minería, Boletín: 1-92. Buenos Aires.

Orihashi, Y.; Naranjo, J.A.; Motoki,A.; Sumino, H.; Hirata, D.; Anma, R.; Nagao, K. 2004. Quaternary volcanic activity of Hudson and Lautaro volcanoes, Chilean Patagonia: new constraints from K-Ar ages. Revista Geológica de Chile 31 (2): 207-224. doi: 10.5027/ andgeoV31n2-a02.

Pasquarè, G.; Bistacchi, A; Francalanci, L.; Bertotto, G.W.; Boari, E.; Massironi, M.; Rossotti, A. 2008. Very long pahoehoe inflated basaltic lava flows in the Payenia Volcanic Province (Mendoza and La Pampa, Argentina). Revista de la Asociación Geológica Argentina 63: 131-149.

Quidelleur, X.; Carlut, J.; Tchilinguirian, P.; Germa, A.; Gillot, P.Y. 2009. Paleomagnetic directions from midlatitude sites in the southern hemisphere (Argentina): contribution to time averaged field models. Physics of the Earth and Planetary Interiors 172: 199-209.

Ramos, V.A.; Kay, S.M. 2006. Overview of the tectonic evolution of the southern Central Andes of Mendoza and Neuquén (35-39 S latitude). Geological Society of America, Special Papers 407: 1-17.

Ramos, V.A.; Folguera,A. 2011. Payenia volcanic province in the Southern Andes: an appraisal of an exceptional Quaternary tectonic setting. Journal of Volcanology and Geothermal Research 201: 53-64.

Ramos, V.A.; Litvak, V.D.; Folguera, A.; Spagnuolo, M. 2014.AnAndean tectonic cycle: from crustal thickening to extension in a thin crust $\left(34^{\circ}-37^{\circ} \mathrm{SL}\right)$. Geoscience Frontiers 5 (3): 351-367.

Risso, C.; Németh, K.; Combina, A.M.; Nullo, F.; Drosina, M. 2008. The role of phreatomagmatism in a Plio-Pleistocene high-density scoria cone field: 
Llancanelo Volcanic Field (Mendoza), Argentina. Journal of Volcanology and Geothermal Research 169: 61-86.

Rossi, M.J. 1996. Morphology and mechanism of eruption of postglacial shield volcanoes in Iceland. Bulletin of Volcanology 57 (7): 530-540.

Rossi, M.J.; Gudmundsson, A. 1996. The morphology and formation of flow-lobe tumuli on Icelandic shield volcanoes. Journal of Volcanology and Geothermal Research 72 (3-4): 291-308.

Self, S.; Thordarson, Th.; Keszthelyi, L.; Walker, G.P.L.; Hon, K. 1996. A new model for the emplacement of the Columbia River Basalts as large inflated pahoehoe sheet lava flow fields. Geophysical Research Letters 23: $2689-2692$.

Self, S.; Keszthelyi, L.; Thordarson, Th. 1998. The importance of pahoehoe. Annual Review of Earth and Planetary Sciences 26: 81-110.

Self, S.; Jay, A.E.; Widdowson, M.; Keszthelyi, L.P. 2008. Correlation of the Deccan and Rajahmundry Trap lavas: Are these the longest and largest lava flows on Earth? Journal of Volcanology and Geothermal Research 172 (1): 3-19.

Shaw, H.R. 1972. Viscosities of magmatic silicate liquids: an empirical method of prediction. American Journal of Science 272: 870-893.

Scarfe, C.M. 1973. Viscosity of basic magmas at varying pressure. Nature Physical Science 241: 101-102.

Sobral, J.M. 1942. Geología de la región occidental del Territorio de La Pampa, situada al occidente del Chadi-Leuvú. Boletín de Informaciones Petroleras 212: 33-81. Buenos Aires.

Stephenson, P.J.; Griffin, T.J. 1976. Some long basaltic lava flows in North Queensland. In Volcanism in Australia (Johnson, R.W; editor). Elsevier: 41-51. Amsterdam.
Stephenson, P.J.; Burch-Johnston, A.T.; Stanton, D.; Whitehead, P.W. 1998. Three long lava flows in north Queensland. Journal of Geophysical Research: solid earth 103 (B11): 27359-27370.

Thordarson, Th. 1995. Volatile release and atmospheric effects of basaltic fissure eruptions. Ph.D. Thesis (Unpublished), University of Hawaii: 580 p.

Thordarson, Th.; Self., S. 1996. Sulfur, chlorine and fluorine degassing and atmospheric loading by the Roza eruption. Columbia River Basalt Group, Washington, USA. Journal of Volcanology and Geothermal Research 74: 49-74.

Walker, G.P.L. 1991. Structure, and origin by injection under surface crust of tumuli, "lava rises," "lava-rise pits" and "lava inflation clefts" in Hawaii. Bulletin of Volcanology 53 (7): 546-558.

Waters, A.C. 1961. Stratigraphic and lithologic variations in the Columbia River basalt. American Journal of Science 259 (8): 583-611.

Wentworth, C.K.; Macdonald G.A. 1953. Structures and forms of basaltic rocks in Hawaii. United States Geological Survey, Bulletin 994: 98 p.

Whitehead, P.W.; Stephenson, P.J. 1998. Lava rise ridges of the Toomba basalt flow, north Queensland, Australia. Journal of Geophysical Research 103 (B11): 27371 27382.

Wichmann, R. 1928. Contribución a la Geología de los departamentos Chical Co y Puelén, de la parte occidental de La Pampa Central. Dirección General de Minas, Geología e Hidrogeología, Publicación 40: 33 p. Buenos Aires.

Wilmoth, R.A.; Walker, G.P.L. 1993. P-type and S-type pahoehoe: A study of vesicle distribution patterns in Hawaian lava flows. Journal of Volcanology and Geothermal Research 55: 129-142.

Manuscript received: March 14, 2018; revised/accepted: September 25, 2018; available online: January 31, 2019. 